\title{
Às Vésperas da Abolição Um Estudo sobre a Estrutura da Posse de Escravos em São Cristóvão (RJ), 1870
}

\author{
José Flávio Motta \\ Nelson Nozoe \\ Iraci del Nero da Costa
}

Prof. da FEA-USP e do Programa de Pós-Graduação em História Econômica da FFLCH-USP

Prof. da FEA-USP e do Programa de Pós-Graduação em História Econômica da FFLCH-USP

Professor Livre-Docente da FEA-USP

\section{RESUMO}

A primeira parte deste artigo revela a estrutura da posse de escravos de São Cristóvão em 1870, quando essa freguesia já integrava o perímetro urbano do município neutro. Assim, mostramos tal estrutura às vésperas da Abolição em um centro urbano dos mais dinâmicos do Império. É corroborado o padrão estabelecido pela historiografia acerca do escravismo brasileiro: forte presença de escravistas de porte modesto, difusão relativamente ampla da instituição e inexistência de grande concentração na posse de cativos. $O$ escravismo apresenta, no caso analisado, o mesmo perfil básico identificado desde inícios do Setecentos, nos mais diversos pontos do Brasil. Na segunda parte, confrontamos nossos resultados com os de vários outros estudos, respeitantes a diversas localidades brasileiras consideradas em diferentes momentos, apontando as semelhanças e disparidades observadas. De um lado, situamos São Cristóvão no universo do escravismo brasileiro; de outro, perseguimos o conhecimento mais largo e profundo das estruturas demo-econômicas de nossa sociedade escravista.

\section{PALAVRAS-CHAVE}

estrutura da posse de escravos, Brasil história, economia da escravidão, escravismo, demografia histórica

\section{ABSTRACT}

The first part of this paper shows the slaveholding structure in São Cristóvão in 1870, when that parish already belonged to the urban perimeter of the capital city of Rio de Janeiro. Thus that structure can be seen on the eve of Abolition in one of the most dynamic urban centers of the Empire. The results validate the pattern of Brazilian slavery determined by historiography: a great weight of the small slaveholders, the institution of slavery was relatively widespread and slaveholding was not strongly concentrated. The case in focus shows the same basic characteristics of slavery seen since the early 1700s in different parts of Brazil. In the second part, our results are compared to those of several other studies of various localities examined in different moments, showing the similarities and differences observed. On the one hand, São Cristóvão is situated in the universe of Brazilian slavery; on the other, we seek a more wide and profound knowledge of the demo-economic structures of our slave society.

KEY WORDS

slaveholding structure, Brazilian history, economy of slavery, slavery, historical demography

JEL Classification 


\section{INTRODUÇÃO}

$\mathrm{O}$ material deste trabalho distribui-se, basicamente, em duas partes. $\mathrm{Na}$ primeira, composta pelas três seções subseqüentes, retomamos os resultados apresentados no estudo intitulado $A$ posse de escravos em uma paróquia fluminense: São Cristóvão, 1870. (MOTTA, NOZOE \& COSTA, 2002). Tais resultados correspondem, estritamente, à caracterização da estrutura da posse de cativos da paróquia aqui contemplada. Já na segunda parte, integrada pela seção denominada "Estrutura da posse de escravos em São Cristóvão: uma abordagem comparativa”, efetuamos uma série de confrontos entre os dados concernentes à dita paróquia e os que, colhidos em vários outros estudos, dizem respeito à aludida estrutura observada em diversos núcleos localizados em distintos pontos geográficos do Brasil e considerados em diferentes momentos do tempo. Preocupou-nos, aqui, essencialmente, estabelecer as semelhanças e disparidades existentes entre os variados conjuntos de dados analisados. Nosso intuito ao desenvolver esta segunda parte foi, pois, duplo. De um lado procuramos situar São Cristóvão no universo do escravismo brasileiro; de outro, perseguimos o conhecimento mais largo e profundo das estruturas que enformaram nossa sociedade escravista.

\section{SÃO CRISTÓVÃO, 1870}

O momento por nós contemplado neste artigo, 1870, integra uma etapa privilegiada da história da escravidão no Brasil. Especificamente no que respeita ao tema analisado, a estrutura da posse de escravos, tal momento parece-nos especial porque se coloca imediatamente antes das alterações nos padrões de distribuição da propriedade de cativos decorrentes da Lei do Ventre Livre (1871) e, portanto, da dos Sexagenários (1885). Poderemos, pois, observar como se apresentava a estrutura da posse de escravos, às vésperas das referidas mudanças, na freguesia de São Cristóvão, ${ }^{1}$ a qual

1 A fonte primária da qual nos servimos neste trabalho, manuscrita pelos próprios moradores da "Parochia de São Cristóvão do Município da Corte", diz respeito ao arrolamento da população daquele Município realizado em abril de 1870. Tal documentação, pertencente ao acervo da Biblioteca Central do IBGE, vai discriminada nas Referências Bibliográficas como IBGE (MSS). 
já compunha o perímetro urbano do Rio de Janeiro. Essa cidade, além da relevância que a distinguia como sede do Império, definia-se como um dos principais aglomerados populacionais do País; era, não obstante, afetada, também do ponto de vista demográfico, pela proximidade da área rural, onde se destacava a grande produção cafeeira. Essa lavoura, como sabido, via-se, à época, às voltas com o impacto do assim chamado problema da mão-deobra. Era, pois, em quadro dos mais dinâmicos que se movimentavam os habitantes da freguesia objeto de nossa análise. ${ }^{2}$

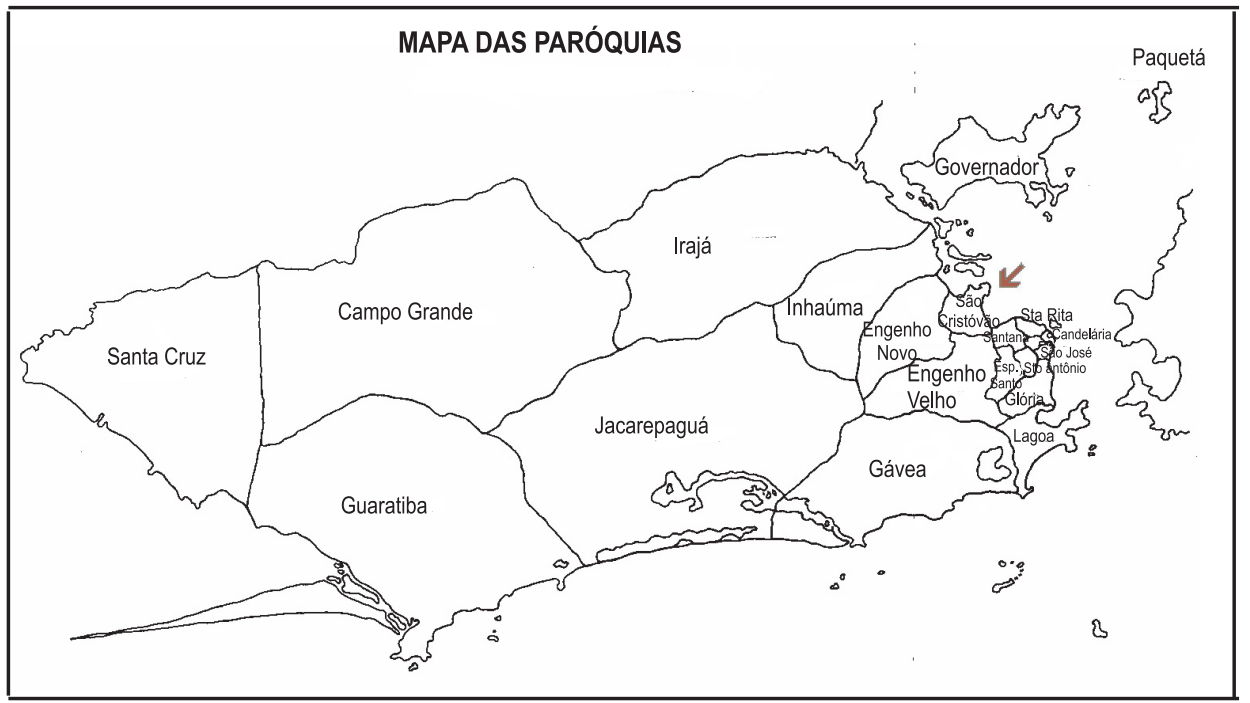

Fonte: LOBO (1978, v. 1, p. 236-A).

2 Como anotou Eulalia Lobo, "pelo Rio de Janeiro escoava a riqueza dos cafezais do planalto, concentrando assim o movimento comercial desta atividade que se estendia pelas terras fluminenses, Zona da Mata, Espirito Santo e nordeste paulista. As estradas de ferro, que foram abertas para servir a região, reforçaram a liderança da cidade como canalizadora das exportaçôes de café sem concorrência substancial até 1890. O Rio de Janeiro era também centro redistribuidor de escravos, abastecedor das fazendas, importador de produtos manufaturados e ponto de convergência do comércio de cabotagem. Essa hipertrofia comercial será capaz de fundamentar todas as nuances da vida urbana no correr do século XIX.” (LOBO, 1978, v. 1, p. 155). Não obstante, "o Rio de Janeiro ainda possuía um setor agrário importante no século XIX. Não havia nesse perído uma ruptura entre o meio urbano e o rural. [...] O Almanack Laemmert de 1857 recenseava 28 fazendas de cana-de-açucar, sete de aguardente, 150 de café, duas de gado e sete de produção indefinida. Esses dados mostram a predomináncia absoluta da plantação do café. O total das propriedades agrárias fornecido por essa fonte, 199, ficava muito aquém do total de 887 do Censo de 1856, provavelmente porque este incluía pequenas e médias propriedades e o Almanack apenas plantaçôes. [...] Em 1892, um Censo da Diretoria de Higiene e Assistência Pública do Rio de Janeiro dava um total de 49 hortas e capinzais nas circunscriçôes urbanas e 246 hortas e capinzais e 122 lavouras nas suburbanas. Nota-se, portanto, o gradual declínio da plantação em consequiência do crescimento e consolidação da manufatura, da expansão do comércio e do aperfeiçoamento do sistema de transportes.” (LOBO, 1978, v. 1, p. 162-163). 
No período examinado neste artigo, o território do Município Neutro achava-se dividido em 19 paróquias, que vão representadas no Mapa acima, das quais 11 urbanas ou "de dentro" e 8 conhecidas como freguesias "de fora" ou rurais $;^{3}$

“(...) a população estará mais concentrada nas chamadas freguesias de dentro, isto é, naquelas que, pela proximidade do porto, representam os centros de atividade econômica da região. Desde 1850 ao final do século, a população se espalha, povoando as freguesias mais afastadas, mas o centro nervoso, o mercado de trabalho da cidade, continua sendo as velhas freguesias de origem comercial. $[. .$.

"As freguesias de fora, o chamado sertão carioca, possuiam uma população mais dispersa e em numero bastante inferior às paróquias urbanas. Sua economia de coleta, artesanato, pecuária e horticultura abastece o centro urbano." (MOURA, 1988, p. 27 e 29).

A freguesia de São Cristóvão foi criada em 1856, com base em desmembramento do território da paróquia do Engenho Velho. ${ }^{4}$ Embora se distinguisse como núcleo basicamente residencial que contava com regular comércio

3 Eram urbanas as paróquias da Candelária, São José, Santa Rita, Sacramento, Glória, Santana, Santo Antonio, Espírito Santo, Engenho Velho, Lagoa e São Cristóvão; as rurais eram as de Irajá, Jacarepaguá, Inhaúma, Guaratiba, Campo Grande, Santa Cruz, Ilha do Governador e Ilha de Paquetá. No Mapa que extraímos do estudo de Eulália Lobo constam também as freguesias da Gávea e do Engenho Novo. A primeira, de Nossa Senhora da Conceição da Gávea, foi criada em 1873 (Decreto Legislativo 2297, de 18 de junho), desmembrada da freguesia de São João Batista da Lagoa; a segunda, igualmente criada em 1873 (Decreto 2335, de 2 de agosto), teve seu território separado das freguesias de São Cristóvão, Inhaúma e Engenho Velho (cf. SANTOS, 1965, p. 36 e 56). Em suma, a São Cristóvão recenseada em 1870, objeto deste artigo, conformaria, de fato, uma área algo maior do que a representada no Mapa, pois à época do arrolamento a freguesia do Engenho Novo ainda não havia sido estabelecida.

4 "a freguesia de S. Cristónão foi criada pelo Decreto de 9 de agosto de 1856, separando-se o seu território do $2^{\circ}$ distrito do Engenho Velho, e do qual fazia parte, por aviso da mesma data. A primitiva freguesia foi alterada pelos Decs. $n^{\circ}$ s. 1255, de 8 de julho de 1865, e 2335, de 2 de agosto de 1873, que lhe desanexaram partes para as freguesias do Espírito Santo e do Engenho Novo, e ainda pelos Decs. $n$ s. 434, 864 e 3816.” (SANTOS, 1965, p. 131). 
local, albergava também alguns estabelecimentos fabris de tecidos, artefatos de barro, de velas e de vidros e cristais. ${ }^{5} \mathrm{O}$ Matadouro Municipal, cujas obras de construção do edifício e dos tendais haviam sido iniciadas em 1846, foi lá inaugurado em 1853, onde permaneceu até 1881, ano a partir do qual se passou a cogitar de sua transferência para Santa Cruz. Em São Cristóvão localizavam-se três cemitérios, ${ }^{6}$ o Hospício de Nossa Senhora do Socorro, mantido pela Santa Casa de Misericórdia, e o Hospital dos Lázaros, administrado pela Irmandade do Santíssimo Sacramento da Candelária. A freguesia era servida pela Estrada de Ferro D. Pedro II, que atravessava parte dos terrenos da Quinta da Boa Vista, onde se erguia a Estação São Cristóvão.

O estabelecimento da residência da família imperial na Real Quinta da Boa Vista deveu-se à iniciativa de um negociante da rua Direita, Elias Antônio Lopes, que, pouco tempo depois da chegada de D. João ao Rio de Janeiro, ofereceu para morada do regente a quinta de sua propriedade, em São Cristóvão, naquele tempo a melhor casa dos arrabaldes cariocas. Assim, a incorporação ao perímetro urbano da área onde posteriormente seria instalada a freguesia em tela esteve associada à vinda das Cortes. Ademais, tal incorporação viu-se facilitada com a construção de interligações terrestres da Quinta com o núcleo central da urbe. Schlichthorst, em livro publicado originalmente em Hanover em 1829, deixou-nos uma pitoresca e picante descrição dos meios de acesso à localidade:

"Por terra dois caminhos para lá conduzem: o chamado Caminho das Lanternas, estrada retissima através do mangue que separa o Rio de Janeiro de S. Cristóvão; e outro, chamado

5 "Entre estas freguesias [Candelária, Sacramento, Santana, Santo Antônio, São José e Santa Rita] e o sertão carioca encontramos regióes como a antiga freguesia da Capela Real, ou São Cristóvão, que possui grandes fábricas de vidros, cerâmicas, velas nacionais e de tecidos (...).” (MOURA, 1988, p. 28).

6 Eram o Cemitério da Irmandade da Venerável Ordem $3^{\text {a }}$ do Carmo (inaugurado em 1859, por ocasião da febre amarela e por ter o governo proibido enterramentos nas igrejas), o Cemitério da Irmandade da Venerável Ordem $3^{\mathrm{a}}$ da Penitência (inaugurado em 1858) e o Cemitério do Caju ou de São Francisco Xavier, público, dirigido pela Santa Casa de Misericórdia. Este último era o maior da cidade e foi inaugurado em 1840, com o nome de Cemitério do Caju, denominação conservada até 1851, quando se passou a denominar Cemitério de S. Francisco Xavier; possuía uma quadra especial onde eram enterrados os irmãos da Confraria de S. Pedro e os israelitas (cf. SANTOS, 1965, p. 128). 
Caminho Mata Porcos, menos cômodo e mais romântico, que parte do Catumbi e corre entre os morros e a borda do pantanal. A comunicação mais preferida é feita por mar, em canoas e barcos, que vão e vêm, sem interrupção, de diversos pontos da cidade. Foi D. João VI quem mandou construir, com grande despesa, o Caminho das Lanternas. As colunas de pedra colocadas dos dois lados, de $50 \mathrm{em} 50$ passos, para sustentarem as incontáveis lanternas, que se acendiam quando o monarca, à noite, ia à cidade ou se recolbia a $S$. Cristópão, testemunham que, entre as suas virtudes, ele não possuía a coragem pessoal. O Imperador corre muito maior risco que seu real pai, mas despreza o perigo. Dizem que mais de uma vez já the deram tiros nesse caminho. Apesar disso, nunca mandou acender os lampiões. D Pedro costuma dizer - 'Sei que minha mãe é uma ... mas devo-lhe ter-me parido sem medo!'. E passa por ali a qualquer hora da noite." (SCHLICHTHORST, 1943, p. 50-51).

O relatório sobre o arrolamento da população do Município da Corte em 1870 (RELATÓRIO, 1871) menciona que, naquele ano, encontravam-se em São Cristóvão 3,8\% dos fogos da cidade e ali residiam 3,9\% da população livre (7.303 indivíduos em um total de 185.289), porcentual igualmente válido para o contingente escravo (1.969 cativos em uma massa escrava de 50.092 ). Na paróquia examinada, bem como no município como um todo, a participação dos escravos na população total era levemente superior a um quinto (cerca de 21,2\%). Não obstante o fato de estarmos a lidar, tão-somente, com pouco menos de $4 \%$ da população total, acreditamos que os resultados alcançados com base no estudo estatístico dos moradores de São Cristóvão nos propiciam o delineamento de um perfil de estrutura da posse de cativos que, em suas linhas gerais, não deve se distanciar muito largamente da estrutura de posse vigente na cidade do Rio de Janeiro. Evidentemente, mesmo que esse perfil nos pareça razoavelmente aproximado daquele vigorante na urbe, cabe frisar ser preciso ter presente que as peculiaridades das 
distintas paróquias integrantes do Município da Corte refletiam-se nitidamente em alguns de seus indicadores quantitativos.

\section{ESCRAVISTAS E ESCRAVOS: UMA VISÃO DE CONJUNTO}

Em 1870, cerca de um quarto dos fogos de São Cristóvão contava com a presença de escravos. Os escravistas - em número de 397, que representavam $5,4 \%$ da população livre residente na paróquia - compunham-se majoritariamente de indivíduos do sexo masculino $(72,5 \%)$, predominando os que haviam conhecido o casamento (52,6\% de casados e $24,9 \%$ de viúvos). Pouco menos de três quintos $(58,9 \%)$ haviam nascido no Brasil, os europeus correspondiam a $36,5 \%,{ }^{8}$ os africanos tão-somente a $1,0 \%$, cabendo aos demais estrangeiros a modestíssima participação de 0,8\%. A idade média dos proprietários de cativos elevava-se a 45,4 anos, pouco mais de um terço $(36,4 \%)$ contava com idade inferior a 40 anos, $46,4 \%$ situavam-se na faixa etária entre 40 e 59 anos e os restantes $17,2 \%$ formavam o conjunto dos escravistas com 60 ou mais anos.

7 Por exemplo, tomando as tabulações fornecidas em LOBO (1978, v. 1, p. 263-442), observamos, nas distribuiçóes dos indivíduos livres do sexo masculino de acordo com diferentes "profissões", que do total de 20.574 "comerciantes, guarda-livros e caixeiros" apenas $2,7 \%$ residiam nas oito paróquias rurais, compondo, os $97,3 \%$ restantes, a população das onze paróquias "de dentro". Adicionalmente, levando em conta apenas estas últimas, enquanto em São Cristóvão os homens livres enquadrados como "comerciantes, guarda-livros e caixeiros" correspondiam a $24,0 \%$ do total de homens livres para os quais havia o informe da "profissão", na freguesia da Candelária, por exemplo, o porcentual correlato alçava-se a $81,9 \%$. Como avançado no texto, não cremos que divergências numéricas tais como essas pudessem alterar decisivamente a estrutura da posse de escravos de São Cristóvão de sorte a fazê-la discrepar muito daquela associada à urbe como um todo. Vale dizer, e aqui tomamos apenas o exemplo por nós fornecido, embora em São Cristóvão houvesse uma presença relativamente menos marcante de "comerciantes, guarda-livros e caixeiros", não temos razões para supor que a estrutura da posse de cativos desses indivíduos em "nossa" freguesia fosse radicalmente diferente da verificada entre os escravistas "comerciantes, guarda-livros e caixeiros" da Candelária. Consideramos, outrossim, que essa observação pode ser estendida para os demais indicadores numéricos que caracterizavam a estrutura da posse de escravos contemplada neste estudo; de outra parte, entendemos que a ressalva explicitada nesta nota faz-se necessária para alertar o leitor sobre as disparidades existentes entre a freguesia de São Cristóvão e a cidade do Rio de Janeiro tomada como um todo.

8 Computamos, entre os europeus, 129 portugueses, 7 franceses, 3 espanhóis, 2 italianos, cifra igualmente válida para ingleses, e mais dois escravistas: um nascido na Prússia e outro na Holanda. 
O espectro das atividades econômicas desenvolvidas pelos proprietários de escravos confirma o caráter tipicamente urbano da freguesia. Assim, ao comércio dedicava-se pouco menos de um terço $(30,7 \%)$ do número de indivíduos em questão; os proprietários e rentistas, por sua vez, correspondiam a $13,6 \%$; as profissões liberais $(8,1 \%)$ e a magistratura e funcionários civis $(11,1 \%)$ reuniam em conjunto aproximadamente um quinto dos escravistas, seguindo-se o artesanato com 7,0\%. Em contrapartida, a agricultura e as atividades do mar não atingiam, em conjunto, mais do que 2,3\%. ${ }^{9}$ Para 84 $(21,1 \%)$ dos possuidores de cativos não obtivemos o informe da atividade econômica com a qual estavam envolvidos. ${ }^{10}$

Nos documentos que nos chegaram, anotou-se a presença de 1.625 escravos em São Cristóvão. Não obstante também levar em conta os escravos de aluguel, este número situa-se em patamar inferior àquele apontado pela comissão encarregada da direção dos trabalhos do sobredito arrolamento (1.969 cativos); diferença possivelmente decorrente do extravio de algumas folhas de coleta de dados. Observando a distribuição da população cativa segundo a origem notamos o marcado predomínio dos indivíduos nascidos no Brasil $(68,1 \%)$, ao passo que os africanos correspondiam a menos de três décimos do total $(27,5 \%)$; adicionalmente, eram nove $(0,5 \%)$ os escravos oriundos de Portugal ou das Ilhas Atlânticas e para outros 63 (3,9\%) não foi possível identificar a origem.

A denotar um eventual encaminhamento da mão-de-obra masculina para o meio rural, predominava na massa escrava da paróquia o elemento feminino: $54,5 \%$ versus $42,9 \%$ (com $2,6 \%$ de pessoas para as quais não foi possível a identificação do sexo). Tal suposição vê-se corroborada pelas razões de masculinidade calculadas segundo a origem. $\mathrm{O}$ indicador concernente aos

9 Completam o elenco das atividades econômicas/ocupações dos escravistas de São Cristóvão as seguintes: indústria (4 proprietários de cativos), igreja (3), transporte (1), serviços (5), bem como os três escravistas arrolados como jornaleiros (cf. Tabela 3 adiante).

10 Desses 84 escravistas, quase três quartos $(73,8 \%)$ eram do sexo feminino. Portanto, das pouco mais de cem mulheres proprietárias de cativos, para apenas 46 delas obtivemos o informe da atividade econômica, a saber: agricultoras (1); artesãs (11); proprietárias/rentistas (20); profissionais liberais (3); vinculadas ao comércio (5); aos serviços (5) e uma escravista qualificada como jornaleira. 
brasileiros indicou a existência de 62,6 homens para cada grupo de 100 mulheres; já o índice correlato para africanos igualou-se a 147,3. Dessa forma, dos 1.538 cativos para os quais obtivemos os informes sobre sexo e origem, $43,5 \%$ correspondiam às mulheres nascidas no Brasil, participação significativamente superior à dos homens brasileiros $(27,2 \%)$. Para africanos e africanas, os porcentuais análogos foram, respectivamente, iguais a 17,5\% e $11,8 \%$. Vale dizer, o aventado direcionamento da mão-de-obra masculina para o meio rural afetaria em muito menor grau o segmento africano que, na década de 1870, apresentava-se, decerto, relativamente envelhecido para o cotidiano da faina agrícola. ${ }^{11}$

A observação da pirâmide etária da população cativa de São Cristóvão (Figura 1) sedimenta as considerações tecidas no parágrafo anterior. Assim, verificamos que as mulheres eram mais numerosas até os 39 anos de idade. Essa supremacia numérica das escravas mostrou-se, ademais, crescente nas três primeiras faixas etárias contempladas na pirâmide - 0 a 9, 10 a 19 e 20 a 29 anos -, nas quais a razão de masculinidade igualou-se, respectivamente, a 73,9, 64,4 e 45,9. A mencionada alocação preferencial de parte do contingente cativo masculino no meio rural evidencia-se cada vez mais à medida que se eleva a idade dos indivíduos em tela, e seus efeitos fazem-se sentir com maior contundência entre os escravos na faixa dos 20 anos de idade.

No intervalo entre 30 e 39 anos, as cativas ainda predominavam, mas a razão de masculinidade alçou-se para 83,6. Começa-se a perceber o impacto da presença dos africanos e, sobretudo, da própria destinação preferencial, desta feita de um segmento populacional relativamente mais velho, para as ativi-

11 De fato, tal envelhecimento relativo vê-se corroborado quando consideramos os porcentuais da distribuição dos escravos de acordo com a origem e consoante três grandes faixas etárias. Só se contavam cativos com menos de 15 anos de idade entre os brasileiros, e os indivíduos dessa faixa etária perfaziam mais de um terço dos escravos "nativos". De outra parte, tão-somente cerca de um centésimo dos cativos nascidos no Brasil tinham 60 ou mais anos. No caso dos escravos nascidos no exterior - a grande maioria deles composta, como visto, por africanos -, os mais idosos, no mínimo sexagenários, conformavam aproximadamente um décimo do total, tendo os outros nove décimos idades entre 15 e 59 anos. 
dades de caráter mais nitidamente urbano. A esses dois fatores somar-se-ia, muito provavelmente, a ocorrência de um índice mais elevado de alforrias concedidas a mulheres escravas. Em suma, se na faixa etária de 0 a 39 anos a razão de masculinidade era igual a 67,0 , para a população cativa com 40 ou mais anos de idade tal razão elevava-se para 106,2.

\section{FIGURA 1 - PIRÂMIDE ETÁRIA DA POPULAÇÃO ESCRAVA DA FRE- GUESIA DE SÃO CRISTÓVÃO, 1870}

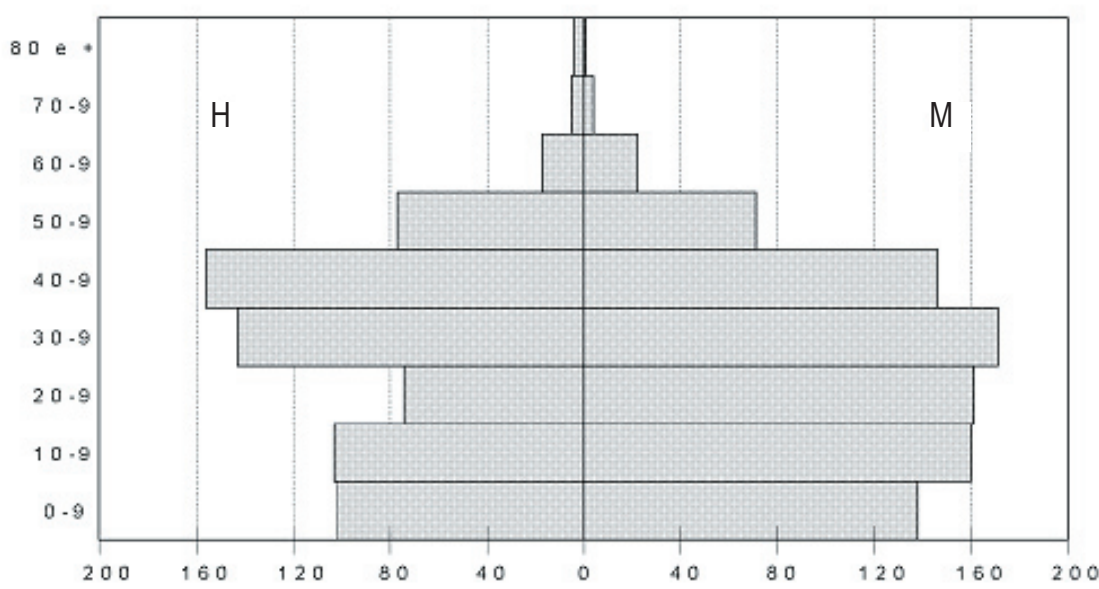

Adicionalmente, no que respeita à consideração conjunta das variáveis sexo e estado conjugal dos cativos, percebemos o significativo predomínio dos solteiros, os quais correspondiam a cerca de três quartos do total de escravos. Essa proporção era um pouco mais alta entre os homens $(77,2 \%)$ comparativamente às mulheres $(73,3 \%)$. Computamos apenas 10 cativos casados $(0,6 \%)$, sendo meia dúzia do sexo feminino, e 5 viúvos $(0,3 \%)$, dois deles do sexo masculino. Ainda que tomemos tão-somente os indivíduos com 15 ou mais anos de idade, mantém-se modestíssima a participação daqueles anotados como casados ou viúvos, igual a 1,3\%. Para quase um quarto dos escravos $(23,7 \%)$ não foi possível determinar o estado conjugal. 


\section{ELEMENTOS DA ESTRUTURA DA POSSE DE ESCRAVOS ${ }^{12}$}

Uma primeira aproximação às características da estrutura da posse de cativos em São Cristóvão é possibilitada pelos informes acerca da distribuição de escravistas e de escravos de acordo com o sexo e segundo faixas de tamanho dos plantéis (Tabela 1). O predomínio dos homens, entre os proprietários, verificou-se em todos os tamanhos de escravarias, sendo ligeiramente menor no caso dos plantéis unitários (taxa de masculinidade igual a 68\%) vis-à-vis às demais faixas (nas quais essa taxa manteve-se em torno de $75 \%$ ). Entre os cativos, a supremacia numérica das mulheres apenas não ocorreu nas maiores posses; de fato, as taxas de masculinidade igualaram-se, respectivamente nas quatro faixas consideradas, a $38 \%, 41 \%, 43 \%$ e $70 \% .^{13}$

Estes quatro últimos porcentuais, recalculados separadamente consoante o sexo dos escravistas, perfizeram as cifras representadas no Gráfico 1. Ainda que o resultado final não se altere - vale dizer, independente do sexo dos proprietários, predomínio das escravas nas três primeiras faixas de tamanho e dos cativos do sexo masculino nos maiores plantéis -, observamos, invariavelmente, taxas de masculinidade superiores, em cada faixa de tamanho, entre os escravos possuídos por proprietários homens. Assim, no caso das escravistas, a taxa de masculinidade dos cativos nos plantéis com 15 ou menos indivíduos oscilou entre $28 \%$ e $35 \%$, elevando-se a $56 \%$ na faixa de 16 a 32 escravos. Nesta mesma faixa, a taxa correlata obtida entre os cativos de proprietários homens foi de $75 \%$, oscilando, nas demais faixas de tamanho, em torno de $44 \%$.

12 Foram considerados, tão-somente, os 1.522 cativos cujos proprietários residiam em São Cristóvão.

13 No cômputo das taxas de masculinidade dos escravos foram excluídos 42 indivíduos para os quais não foi possível determinar o sexo. 
TABELA 1 - DISTRIBUIÇÃO DE ESCRAVISTAS E DE CATIVOS, SEGUNDO SEXO E FAIXAS DE TAMANHO DOS PLANTÉIS (FTP)

\begin{tabular}{|c|c|c|c|c|c|c|c|c|c|c|}
\hline \multirow[b]{2}{*}{ FTP } & \multicolumn{4}{|c|}{ Proprietários } & \multicolumn{4}{|c|}{ Escravos } & \multicolumn{2}{|c|}{ Porcentagens } \\
\hline & $\mathrm{H}$ & M & Ind & $\mathrm{H}+\mathrm{M}$ & $\mathrm{H}$ & M & Ind & $\mathrm{H}+\mathrm{M}$ & Propr & Escr \\
\hline 1 & 86 & 40 & - & 126 & 46 & 76 & 4 & 126 & 31,7 & 8,3 \\
\hline $2-5$ & 138 & 48 & - & 186 & 233 & 332 & 15 & 580 & 46,9 & 38,1 \\
\hline $6-15$ & 58 & 18 & 1 & 77 & 264 & 356 & 23 & 643 & 19,4 & 42,2 \\
\hline $16-32$ & 6 & 2 & - & 8 & 121 & 52 & - & 173 & 2,0 & 11,4 \\
\hline Total & 288 & 108 & 1 & 397 & 664 & 816 & 42 & 1.522 & 100,0 & 100,0 \\
\hline
\end{tabular}

Obs.: $\quad \mathrm{H}=$ Homens; $\mathrm{M}=$ Mulheres; $\mathrm{Ind}=$ Indeterminado; Propr = Proprietários de escravos; Escr $=$ Escravos.

GRÁFICO 1 - TAXAS DE MASCULINIDADE DOS ESCRAVOS, SEGUNDO O SEXO DO PROPRIETÁRIO E DE ACORDO COM A FAIXA DE TAMANHO DO PLANTEL

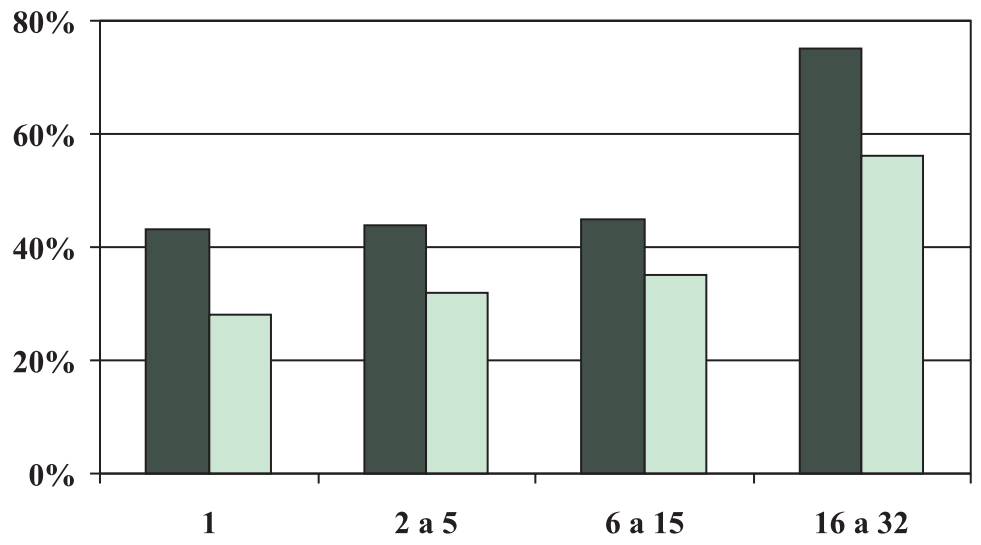

Escravistas homens $\square$ Escravistas mulheres

Ainda com fundamento na Tabela 1 , notamos que pouco menos de quatro quintos $(78,6 \%)$ dos escravistas possuíam 5 ou menos escravos; eram 312 proprietários detentores de 706 cativos (46,4\% da massa escrava total). Nesse conjunto, era marcante a participação dos plantéis unitários: 31,7\% dos escravistas e $8,3 \%$ dos escravos. No extremo oposto da distribuição, os 8 proprietários integrantes da faixa de 16 a 32 cativos correspondiam a tãosomente $2,0 \%$ dos escravistas; não obstante, eram seus $11,4 \%$ dos escravos computados. A maioria relativa dos cativos $(42,2 \%)$ compunha os plantéis 
de 6 a 15 elementos, cujos proprietários perfaziam cerca de um quinto do contingente de escravistas.

Alguns indicadores estatísticos concernentes aos proprietários (Tabela 2) contribuem para o delineamento do perfil da distribuição da posse escrava. O índice de Gini $(0,46)$ evidencia um nível relativamente moderado de concentração da riqueza em cativos, decorrente, em boa medida, das próprias dimensões da quarta e última faixa de tamanho dos plantéis de São Cristóvão, tendo por limite superior uma única escravaria com 32 integrantes. ${ }^{14}$ Os valores da média $(3,8)$, moda (1) e mediana (3), por sua vez, atestam a predominância das posses de menor porte. Além disso, os índices ligeiramente inferiores (média e mediana) calculados no caso das proprietárias aliam-se aos menores valores das taxas de masculinidade dos escravos possuídos por mulheres (Gráfico l) e indicam serem os homens, em média, detentores de maiores recursos, ao menos enquanto medidos pela propriedade de cativos.

Em outras palavras, as escravistas detinham, em média, plantéis menores, nos quais a presença de escravas, mais baratas, era mais intensa em comparação com as escravarias possuídas por proprietários homens. ${ }^{15}$ A condicionar este perfil certamente estavam a eventual "especialização" da escravaria detida por mulheres na produção de bens - alimentos, por exemplo - cujo preparo demandava, preferencialmente, mão-de-obra feminina, e, sobretudo, o grande contingente de viúvas existente no grupo das proprietárias de cativos: enquanto entre os escravistas homens havia apenas $11,5 \%$ de viúvos, a cifra correlata alçava-se a $61,1 \%$ para as escravistas. A viúva tenderia a desfazerse de seu ativo mais valioso (escravos do sexo masculino) seja em face de eventual apertura econômica, seja porque, não disposta a dar continuidade

14 Procedemos, na seção subseqüente deste artigo, a uma comparação entre as características da estrutura da posse de escravos de São Cristóvão e aquelas atinentes a outras localidades brasileiras, na década de 1870 e/ou em períodos anteriores.

15 Vale observar que essa disparidade entre os valores de mercado dos escravos de acordo com o sexo seria posteriormente referendada pela legislação. De fato, na matrícula dos cativos brasileiros determinada pela Lei $\mathrm{n}^{\circ} 3.270$, de 28 de setembro de 1885 , e regulamentada pelo Decreto $\mathrm{n}^{\circ}$ 9.517, de 14 de novembro de 1885 , estabeleceu-se que "o valor seria declarado pelo proprietário do escravo, não excedendo o preço máximo regulado pela idade do matriculado, conforme tabela que consta do artigo $1^{\circ}$ da Lei $[. .$.$] Sendo que o valor dos escravos do sexo feminino teria um abatimento de$ $25 \%$ sobre os preços estabelecidos.” (GRAF, 1974, p. 20, grifo nosso). 
às atividades produtivas do falecido esposo, vendia alguns de seus cativos homens.

\section{TABELA 2 - INDICADORES ESTATÍSTICOS CONCERNENTES AOS ESCRAVISTAS}

\begin{tabular}{lcccc}
\hline Sexo do escravista & Média $^{\text {a }}$ & Moda $^{\text {a }}$ & Mediana $^{\text {a }}$ & Índice de Gini \\
\hline Homens & 4,0 & 1 & 3 & 0,459 \\
Mulheres & 3,5 & 1 & 2 & 0,469 \\
Total $^{\text {b }}$ & 3,8 & 1 & 3 & 0,462 \\
\hline
\end{tabular}

a Os valores da tabela referem-se ao número de escravos possuídos por proprietário.

b Inclusive um escravista cujo sexo não foi possível determinar.

Os valores das médias de escravos possuídos, calculados agora de acordo com diferentes faixas etárias dos proprietários (Gráfico 2), permitem-nos observar os efeitos do ciclo de vida sobre o processo de acumulação em cativos. Muito embora apresentando uma amplitude de variação relativamente discreta (de um mínimo de 2,40 a um máximo de 5,87 escravos por proprietário), ${ }^{16}$ tais valores evidenciam, para São Cristóvão, a corroboração, em linhas gerais, ${ }^{17}$ do impacto esperado:

\section{"Teoricamente, pode-se esperar que o número de escravos varie com a idade do proprietário. Assim, até a faixa dos sessenta-se- tenta anos verificar-se-ia uma correlação positiva entre as duas variáneis. Tal afirmativa parte da hipótese de que o proprietário tenderia a acumular riqueza - neste caso representada pelo número de escravos possuidos - no correr do periodo economi- camente ativo de sua vida. Já para a faixa colocada após os setenta anos - como decorrência de uma eventual partilha em vida ou da não-reposição de escravos falecidos - ocorreria}

16 Amplitude não muito diferente da verificada, por exemplo, para o caso de oito localidades mineiras em 1804 (entre 1,1 e 8,4 cativos por proprietário), e muito próxima da computada, com a exclusão dos escravistas senhores de engenho, para dez localidades paulistas naquele mesmo ano (de um mínimo de 2,7 a um máximo de 6,5); cf. COSTA (1983, p. 126).

17 Cabe frisar o reduzido número de observações nas faixas etárias extremas: 5 escravistas com até 19 anos, 15 na faixa etária de 70 a 79 anos e 6 com 80 e mais anos de idade. 
uma relação inversa entre idade do proprietário e número de cativos.” (COSTA, 1983, p. 121).

\section{GRÁFICO 2 - NÚMERO MÉDIO DE ESCRAVOS POSSUÍDOS, SEGUN- DO FAIXAS ETÁRIAS DOS PROPRIETÁRIOS ${ }^{\mathrm{a}}$}

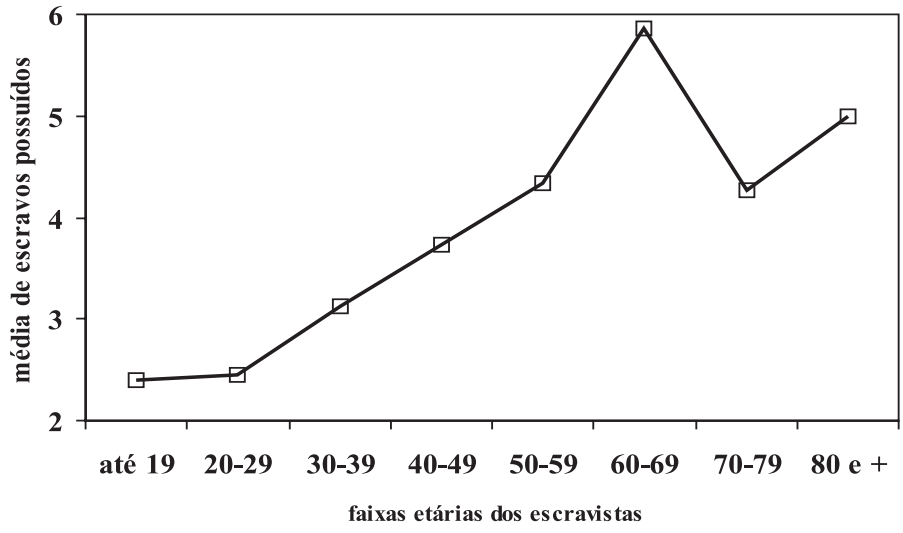

a Excluídos 7 escravistas com idades indeterminadas que, no total, detinham 21 cativos.

O perfil da curva desenhada no Gráfico 2 reflete, também, o espectro de atividades econômicas desempenhadas pelos escravistas de São Cristóvão. ${ }^{18}$ Indicáramos já, na visão de conjunto apresentada na seção precedente deste artigo, que tais atividades patenteavam o caráter urbano da freguesia. Os informes da Tabela 3 atestam que a distribuição dos escravos, de acordo com a variável em questão, acompanhava, grosso modo, a de seus proprietários. De fato, a maioria relativa de escravistas (122 deles, isto é, 30,7\%) e de cativos $(36,1 \%$, correspondendo a 550 indivíduos) vinculavam-se ao comércio, cifras que devem ser entendidas como limites inferiores, tendo em vista desconhecermos as atividades de cerca de um quinto dos indiví-

18 Retomando a breve comparação que ilustrou a nota 16 , a relevância da variável atividade econômica vê-se evidenciada pela consideração à parte dos senhores de engenho paulistas, para os quais o comportamento teórico esperado não se verificou; para esses escravistas, escreveu o autor do estudo em tela, "a curva apresenta oscilaçôes [em torno dos 21 cativos por proprietário] até a faixa dos 60 aos 69 anos para, depois, mostrar-se francamente crescente. É possípel que o comportamento desta curva esteja afetado pelo pequeno numero de observaçóes e por estarmos a trabalhar com dados $\mathrm{em}$ cross-section. Não obstante, [observou-se] a relativa homogeneidade da massa escrava pertencente aos distintos senhores de engenho; tal fato explicaria a inexpressiva variação do número médio de escravos segundo as diversas faixas etárias dos proprietários e estaria a indicar a prevalência de um dimensionamento ótimo da planta dos engenhos paulistas existentes à época.” (COSTA, 1983, p. 123-124). 
duos considerados. ${ }^{19}$ Embora menos expressivos, mostraram-se também relevantes os porcentuais correlatos calculados para as seguintes atividades: "proprietários/rentistas" (13,6\% dos escravistas e 16,2\% dos escravos); "magistratura e funcionários civis" (11,1\% e 8,6\%); e "profissões liberais" $(8,1 \%$ e $7,2 \%)$. Por outro lado, à "agricultura" e às "atividades do mar" dedicavam-se tão-somente $2,3 \%$ dos proprietários, possuidores de $3,6 \%$ do total da escravaria.

O maior tamanho médio dos plantéis (9,5 cativos) correspondia aos 4 indivíduos cuja atividade era a indústria, aos quais se seguiam os agricultores (média de 8,2 escravos por proprietário). Em nenhuma das demais atividades arroladas o indicador estatístico em tela atingiu a marca de 5 cativos; em sete casos - atividades do mar, artesanato, igreja, magistratura e funcionários civis, militares, transporte e serviços -, a média igualou-se ou foi inferior à mediana ( 3 escravos) calculada para o conjunto dos escravistas.

A consideração conjunta das variáveis "atividade econômica dos escravistas" e "faixa de tamanho dos plantéis" (Tabela 4) permite-nos tecer alguns comentários adicionais. ${ }^{20}$ Num meio urbano marcado pela inexistência de posses escravas sobremaneira avantajadas, observamos, de um lado, vários casos em que dominavam, absolutos, os plantéis menores, com até 5 cativos (atividades do mar, igreja, transportes, serviços e jornaleiros); de outro, notamos inexistirem situações de predomínio absoluto dos plantéis na faixa de 16 a 32 integrantes. Mesmo as atividades para as quais foram mais elevadas as médias de escravos possuídos (indústria e agricultura) distribuíam-se por pelo menos três das quatro faixas de tamanho consideradas. No que respeita à atividade mais comum, o comércio, computamos 34 plantéis unitários,

19 Repisemos, ademais, que os cativos, na tabela em questão, vão distribuídos de acordo com a atividade de seus proprietários. Vale dizer, a fonte documental que fundamenta este estudo, tal como acontece para a maior parte dos arrolamentos nominativos produzidos no Brasil nos séculos XVIII e XIX, não nos permite determinar com precisão a ocupação individual dos distintos integrantes dos plantéis de escravos.

20 Tais comentários, é importante ressalvar, padecem, para várias das atividades econômicas contempladas, da vulnerabilidade acarretada pelo reduzido número de observações. 
correspondentes a $27,9 \%$ dos escravistas comerciantes, porcentual que se igualou a, respectivamente, $45,9 \%, 23,8 \%$ e $2,4 \%$ nos plantéis de 2 a 5,6 a 15 e 16 a 32 cativos.

\section{TABELA 3 - DISTRIBUIÇÃO DOS PROPRIETÁRIOS E RESPECTIVOS ESCRAVOS, SEGUNDO AS ATIVIDADES ECONÔMICAS DOS ESCRAVISTAS}

\begin{tabular}{|c|c|c|c|c|}
\hline \multirow[t]{2}{*}{ Atividades } & \multirow[t]{2}{*}{ Escravistas } & \multicolumn{3}{|c|}{ Escravos Possuídos } \\
\hline & & Núm.Abs. & $\%$ & Núm.Médio \\
\hline Agricultura & 6 & 49 & 3,2 & 8,2 \\
\hline Atividades do mar & 3 & 6 & 0,4 & 2,0 \\
\hline Artesanato & 28 & 61 & 4,0 & 2,2 \\
\hline Indústria & 4 & 38 & 2,5 & 9,5 \\
\hline $\begin{array}{l}\text { Proprietários/ } \\
\text { rentistas }\end{array}$ & 54 & 246 & 162 & 46 \\
\hline Igreja & 3 & 4 & 0,3 & 1,3 \\
\hline $\begin{array}{l}\text { Magistratura e } \\
\text { funcionários civis }\end{array}$ & 44 & 131 & 8,6 & 3,0 \\
\hline Militares & 8 & 18 & 1,2 & 2,3 \\
\hline Profissões liberais & 32 & 109 & 7,2 & 3,4 \\
\hline Comércio & 122 & 550 & 36,1 & 4,5 \\
\hline Transporte & 1 & 1 & 0,1 & 1,0 \\
\hline Serviços & 5 & 8 & 0,5 & 1,6 \\
\hline Jornaleiros & 3 & 10 & 0,7 & 3,3 \\
\hline Indeterminadas & 84 & 291 & 19,1 & 3,5 \\
\hline Total & 397 & 1.522 & 100,0 & 3,8 \\
\hline
\end{tabular}

Obs.: Núm.Abs. $=$ Número absoluto; Núm.Médio = Número médio.

Assim sendo, ao caráter urbano da freguesia vinculava-se um elenco de atividades econômicas no qual as possibilidades diferenciadas de acumulação em cativos certamente existiam, todavia não se traduziam na constituição de grandes escravarias, o que, para muitos desses proprietários, decerto não ocorria por conta dos próprios limites da demanda por mão-de-obra cativa afeta às atividades por eles desempenhadas. Tais limites, cabe enfatizar, tendiam a tornar-se mais efetivos numa quadra em que a aquisição de escravos, 
desvinculada da atividade produtiva exercida pelo escravista, vivenciava, de forma cada vez mais intensa, a concorrência propiciada pelo alargamento das possibilidades de aplicação de recursos em ativos alternativos, a exemplo dos títulos da dívida pública e de empresas privadas. ${ }^{21}$

\section{TABELA 4 - DISTRIBUICCÃO DOS ESCRAVISTAS, SEGUNDO SUA ATIVIDADE ECONÔMICA E FAIXAS DE TAMANHO DOS PLANTÉIS (FTP)}

\begin{tabular}{|c|c|c|c|c|c|}
\hline \multirow[t]{2}{*}{ Atividades } & \multicolumn{4}{|c|}{ Escravos Possuídos, por FTP } & \multirow[t]{2}{*}{ Total } \\
\hline & 1 & 2 a 5 & 6 a 15 & 16 a 32 & \\
\hline Agricultura & 1 & 2 & 2 & 1 & 6 \\
\hline Atividades do mar & 1 & 2 & - & - & 3 \\
\hline Artesanato & 13 & 14 & 1 & - & 28 \\
\hline Indústria & - & 2 & 1 & 1 & 4 \\
\hline $\begin{array}{l}\text { Proprietários/ } \\
\text { rentistas }\end{array}$ & 9 & 29 & 15 & 1 & 54 \\
\hline Igreja & 2 & 1 & - & - & 3 \\
\hline $\begin{array}{l}\text { Magistratura e } \\
\text { funcionários civis }\end{array}$ & 17 & 19 & 8 & - & 44 \\
\hline Militares & 4 & 3 & 1 & - & 8 \\
\hline Profissões liberais & 14 & 12 & 5 & 1 & 32 \\
\hline Comércio & 34 & 56 & 29 & 3 & 122 \\
\hline Transporte & 1 & - & - & - & 1 \\
\hline Serviços & 4 & 1 & - & - & 5 \\
\hline Jornaleiros & - & 3 & - & - & 3 \\
\hline Indeterminadas & 26 & 42 & 15 & 1 & 84 \\
\hline Total & 126 & 186 & 77 & 8 & 397 \\
\hline
\end{tabular}

21 Por isso mesmo, em comparação com os anos iniciais do Oitocentos, decai muito, na segunda metade do dito século, a qualidade da distribuição da propriedade de escravos como variável proxy para a análise da distribuição de riqueza. 
TABELA 5 - DISTRIBUIÇÃO DOS ESCRAVISTAS SEGUNDO ORIGEM E FAIXAS DE TAMANHO DOS PLANTÉIS (FTP)

\begin{tabular}{|c|c|c|c|c|c|}
\hline \multirow{2}{*}{$\begin{array}{l}\text { Origem do } \\
\text { Proprietário }\end{array}$} & \multicolumn{2}{|c|}{ FTP: de 1 a 5 cativos } & \multicolumn{2}{|c|}{ FTP: de 6 a 32 cativos } & \multirow[t]{2}{*}{ Total } \\
\hline & Observado & Calculado & Observado & Calculado & \\
\hline Rio de Janeiro & 33 & 33 & 9 & 9 & 42 \\
\hline Brasil $^{a}$ & 156 & 151 & 36 & 41 & 192 \\
\hline África & 4 & 3 & - & 1 & 4 \\
\hline Portugal e llhas & 95 & 101 & 34 & 28 & 129 \\
\hline Europa (outros) & 11 & 13 & 5 & 3 & 16 \\
\hline América do Sul & 2 & 2 & - & - & 2 \\
\hline Estrangeiros $^{\mathrm{b}}$ & 1 & 1 & - & - & 1 \\
\hline Desconhecida & 10 & 9 & 1 & 2 & 11 \\
\hline Total & 312 & & 85 & & 397 \\
\hline
\end{tabular}

Excluídos os fluminenses, incluídos um mineiro e outro natural de Santo Antonio da Mata.

b Sem outra especificação.

Obs.: $\quad x^{2}=6,503$, não significativo; $x^{2}$ tabelado $(7$ graus de liberdade, nível de 0,50$)=6,346$.

Tais características da localidade examinada manifestam-se, também, no relacionamento distinto entre as origens, de escravistas e de cativos, e o tamanho dos plantéis. Tomemos, de início, os proprietários e sua distribuição segundo a origem e de acordo com faixas de tamanho das escravarias (Tabela 5). Ainda que haja algumas divergências entre os valores calculados e observados, ${ }^{22}$ elas são de pequena monta e, como indica o teste estatístico cujos resultados informamos ao pé da tabela, podem ser consideradas irrelevantes, com o que podemos concluir que o porte do escravista não estaria sendo afetado, significativamente, pela sua origem, na São Cristóvão de $1870 .^{23}$

22 Os valores "calculados" reproduzem, para cada uma das duas faixas de tamanho dos plantéis consideradas, as mesmas proporções da distribuição por origem verificada para o total de escravistas, não prevendo, por conseguinte, qualquer influência da origem sobre as posses de escravos. Os valores observados que mais parecem divergir dessa proporcionalidade teoricamente esperada eram os atinentes aos proprietários brasileiros (exclusive fluminenses), os quais seriam ligeiramente "menos abastados" do que o esperado, e os concernentes aos portugueses e demais europeus, que seriam "mais bem abonados" do que prevê a distribuição teórica.

23 O exemplo dos quatro escravistas dedicados à "indústria", todos eles europeus ( 2 franceses e 2 portugueses) é ilustrativo: como visto, se de um lado esta é a atividade econômica na qual computamos a mais elevada média de escravos por proprietário (Tabela 3), por outro, dois desses proprietários possuíam menos de 5 cativos (respectivamente, 4 e 3 ), um deles detinha 11 escravos e o outro era listado com um plantel formado por 20 indivíduos (Tabela 4). 

TABELA 6 - DISTRIBUIÇÃO DOS ESCRAVOS SEGUNDO ORIGEM E
FAIXAS DE TAMANHO DOS PLANTÉIS (FTP)

\begin{tabular}{lrrrrrr}
\hline \multirow{2}{*}{ FTP } & \multicolumn{2}{c}{ Brasil } & & \multicolumn{2}{c}{ África $^{\mathrm{b}}$} & \multirow{2}{*}{ Total } \\
\cline { 2 - 3 } \cline { 6 - 7 } & Observado & Calculado & & Observado & Calculado & \\
\hline 1 & 80 & 85 & & 41 & 36 & 121 \\
$2-5$ & 410 & 400 & & 156 & 166 & 566 \\
$6-15$ & 456 & 434 & & 158 & 180 & 614 \\
$16-32$ & 95 & 122 & & 78 & 51 & 173 \\
Total & 1041 & & & 433 & & 1474 \\
\hline
\end{tabular}

Excluídas 48 pessoas para as quais não foi possível identificar a origem.

b Incluídos 8 cativos originários de Portugal e suas ilhas.

Obs.: $\quad x^{2}=26,594$, significativo ao nível de $99 \% ; x^{2}$ tabelado ( 3 graus de liberdade, nível de 0,99 ) $=11,345$.

Ao contrário, no que respeita aos cativos, mostraram-se estatisticamente significativas as divergências computadas, conforme a origem, entre as distribuições observada e calculada, segundo as distintas faixas de tamanho dos plantéis (Tabela 6). Assim, a presença de africanos mostrou-se ligeiramente maior do que a esperada nos plantéis unitários $(9,5 \%$ do total de africanos na distribuição observada versus $8,3 \%$ na calculada), diferença que se alargou na faixa de 16 a 32 escravos (18,0\% versus $11,8 \%)$. Em tais segmentos, portanto, verificamos as maiores participações relativas de indivíduos provenientes da África: 33,9\% dos integrantes dos plantéis unitários, porcentual que se eleva a $45,1 \%$ nas maiores escravarias (Gráfico 3). Nas duas outras faixas de tamanho foram os brasileiros que se fizeram mais presentes do que o esperado $(39,4 \%$ do total de brasileiros na distribuição observada versus $38,4 \%$ na calculada, nos plantéis com 2 a 5 cativos; e $43,8 \%$ versus $41,7 \%$ naqueles com 6 a 15 indivíduos). 


\section{GRÁFICO 3 - PARTICIPAÇÕES RELATIVAS DOS ESCRAVOS AFRICA- NOS, SEGUNDO FAIXAS DE TAMANHO DOS PLANTÉIS}

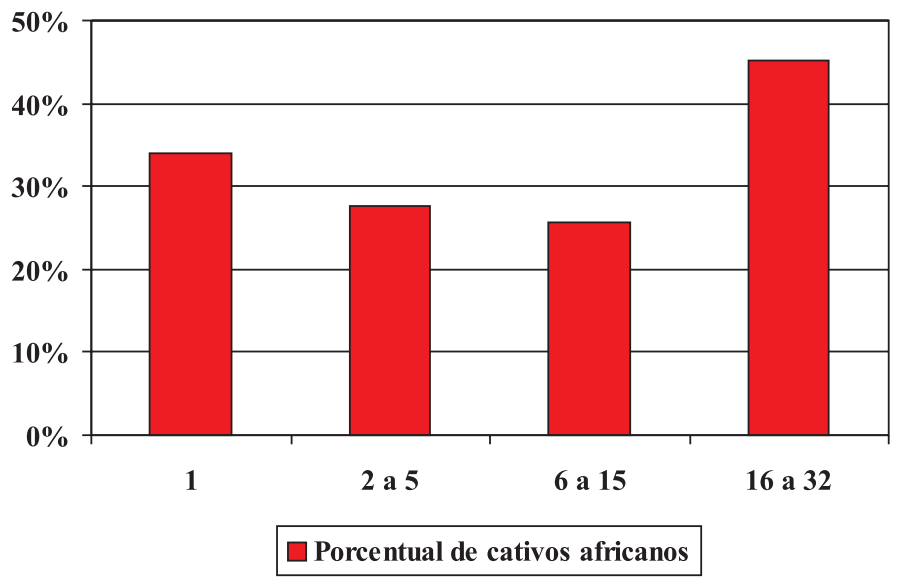

Como se vê, tais divergências apresentam-se mais nítidas no caso dos maiores plantéis. De fato, considerada tão-somente a população escrava africana, percebemos radicar na última das faixas de tamanho contempladas - de 16 a 32 escravos - a mais expressiva supremacia numérica dos indivíduos do sexo masculino: a taxa de masculinidade entre os africanos desses plantéis atingiu $80,8 \%$. Esse indicador alçou-se a $57,5 \%, 55,5 \%$ e $53,5 \%$, respectivamente, nos plantéis unitários, com 2 a 5 e com 6 a 15 cativos. ${ }^{24}$ Convergem, pois, novamente, as maiores posses de escravos e aquelas formadas por cativos, em média, mais valiosos. Não obstante, tal convergência não se vê reforçada por eventuais disparidades no tocante à distribuição etária dos africanos observada nas distintas faixas de tamanho (Tabela 7). Muito embora, por exemplo, os escravos com 15 a 59 anos de idade existentes nos plantéis com 16 a 32 cativos superem a cifra da distribuição calculada, as diferenças verificadas entre os valores observados e calculados não são estatisticamente significativas, $\mathrm{o}$ que implica dizer que a distribuição dos africanos pelos distintos tamanhos dos plantéis independe do perfil etário daqueles indivíduos. ${ }^{25}$

24 No cálculo das taxas de masculinidade entre os escravos africanos foram desconsiderados 5 indivíduos, para os quais não foi possível determinar o sexo.

25 É oportuno ter em vista que o conjunto dos dados apresentados na Tabela 7, alterado pela segmentação da faixa etária dos 15 aos 59 anos em duas outras (de 15 a 39 e de 40 a 59 anos), quando submetido ao teste de quiquadrado, continuou produzindo resultados não significativos. 
TABELA 7 - DISTRIBUICÃO DOS ESCRAVOS AFRICANOS SEGUNDO FAIXAS ETARIAS E FAIXAS DE TAMANHO DOS PLANTÉIS (FTP)

\begin{tabular}{|c|c|c|c|c|c|c|c|}
\hline \multirow{2}{*}{ FTP } & \multicolumn{3}{|c|}{ Observado } & \multicolumn{3}{|c|}{ Calculado } & \multirow{2}{*}{ Total } \\
\hline & $0-14$ & $15-59$ & $60 e^{+}$ & $0-14$ & $15-59$ & $60 \mathrm{e}^{+}$ & \\
\hline 1 & - & 38 & 3 & - & 37 & 4 & 41 \\
\hline $2-5$ & - & 136 & 20 & - & 141 & 15 & 156 \\
\hline $6-15$ & - & 134 & 15 & - & 134 & 15 & 149 \\
\hline $16-32$ & - & 74 & 4 & - & 70 & 8 & 78 \\
\hline Total & - & 382 & 42 & & & & 424 \\
\hline
\end{tabular}

${ }^{a}$ Incluídos 8 cativos vindos de Portugal e suas ilhas e excluídos 9 para os quais não constou a idade.

Obs.: $x^{2}=3,792$, não significativo; $x^{2}$ tabelado ( 3 graus de liberdade, nível de 0,70 ) =3,665.

As duas décadas transcorridas da extinção do tráfico transatlântico de cativos à feitura do recenseamento que embasa este estudo respondem, decerto, em boa medida, por essa indistinção verificada no tocante às distribuições etárias dos africanos pelos diversos tamanhos dos plantéis de São Cristóvão. Indistinção que não se mantém ao considerarmos tão-somente os escravos brasileiros (Tabela 8). Entre estes, idades e porte das escravarias não são, de modo algum, variáveis independentes. Além disso, a comparação entre os valores observados e calculados, fornecidos na tabela mencionada, permitenos perceber que, desta feita, as maiores divergências não radicam na faixa de tamanho de 16 a 32 cativos. De fato, notamos haver, nos plantéis com 1 a 5 cativos, menos crianças de 0 a 14 anos do que o esperado, relação que se inverte na faixa de 6 a 15 indivíduos. Identificamos, subjacente a essas discrepâncias, uma característica comum: o predomínio do sexo feminino, igualando-se a taxa de masculinidade, entre os escravos na faixa etária em questão, a $28,6 \%, 44,8 \%, 42,9 \%$ e $42,9 \%$, respectivamente, nas quatro faixas de tamanho dos plantéis consideradas. 


\section{TABELA 8 - DISTRIBUIÇÃO DOS ESCRAVOS BRASILEIROS SEGUN- DO FAIXAS ETÁRIAS E FAIXAS DE TAMANHO DOS PLANTÉIS (FTP) ${ }^{\mathrm{a}}$}

\begin{tabular}{lrrrrrrrrr}
\hline \multirow{2}{*}{ FTP } & \multicolumn{3}{c}{ Observado } & & \multicolumn{3}{c}{ Calculado } & Total \\
\cline { 2 - 3 } & $0-14$ & $15-59$ & $60 \mathrm{e}^{+}$ & & $0-14$ & $15-59$ & $60 \mathrm{e}+$ & \\
\hline 1 & 22 & 55 & 3 & & 29 & 50 & 1 & 80 \\
$2-5$ & 135 & 270 & 2 & & 147 & 257 & 3 & 407 \\
$6-15$ & 180 & 269 & 3 & & 163 & 285 & 4 & 452 \\
$16-32$ & 35 & 59 & 1 & & 34 & 60 & 1 & 95 \\
Total & 372 & 653 & 9 & & & & & 1034 \\
\hline
\end{tabular}

a Excluídas 7 pessoas para as quais não constou a idade.

Obs.: $x^{2}=14,935$, significativo ao nível de $95 \% ; x^{2}$ tabelado ( 6 graus de liberdade, nível de 0,95 ) $=12,592$.

A distribuição etária e a partição por sexo das crianças cativas revelam, ao que tudo indica, dois movimentos simultâneos. De um lado, sendo todos, meninos e meninas, brasileiros, dever-se-ia verificar relativo equilíbrio entre os sexos, a menos que se fizesse presente algum fluxo de "entrada" ou "saída" desses jovens. Por conseguinte, em São Cristóvão, a supremacia numérica das crianças do sexo feminino evidencia uma possível "saída" de meninos, a qual, de resto, deveria refletir o deslocamento da mão-de-obra masculina para o trabalho rural. Com isso, afastamos a hipótese de que essa "falta" de meninos redundasse de um processo diferencial de manumissões de acordo com o sexo porque, como sabido, a alforria era concedida, preferencialmente, às mulheres; igualmente pouco plausível parece-nos a idéia de que haveria uma generalizada "entrada" (compra) mais do que proporcional de meninas por parte dos escravistas residentes na paróquia ora analisada. ${ }^{26}$

Quanto ao segundo dos movimentos aludidos, havia, ao que parece, nas escravarias formadas por 6 a 15 cativos, comparadas às demais, maior propensão a "reter" escravos com 14 ou menos anos de idade. É justamente

26 Ainda que, nos plantéis menores, e em especial nos unitários, esta última hipótese não deva ser descartada in limine. Por exemplo, ao verificarem uma taxa de masculinidade de $40,0 \%$ entre os escravos presentes nos plantéis unitários de Lorena em 1801, Costa e Nozoe sugerem “... que o ingresso à condição de escravista dava-se, preferencialmente, mediante a propriedade de um escravo do sexo feminino.” (COSTA \& NOZOE, 1989, p. 331). 
isto que se infere dos dados concernentes, segundo faixas de tamanho dos plantéis, à participação relativa dessas crianças sobre o número total de cativos congregados em cada uma das faixas. Assim, enquanto 29,3\% dos integrantes das posses com 6 a 15 indivíduos contavam 14 ou menos anos, para as demais faixas o peso relativo correlato não superava os $24 \%$ (plantéis unitários com $17,6 \%$; de 2 a 5 escravos com $23,6 \%$ e de 16 a 32 cativos com 20,2\%). É interessante notar que este resultado, aliado a outros mais, evidenciados neste e noutros estudos, indica que as distintas faixas de tamanho dos plantéis compunham microcosmos com características próprias e relações sóciodemográficas peculiares. ${ }^{27}$

A Tabela 9 permite-nos refinar um pouco mais a caracterização dessa aventada maior propensão a "reter" crianças escravas nos plantéis de 6 a 15 cativos. A comparação dos valores porcentuais fornecidos nas duas últimas colunas da tabela em questão evidencia que esse traço das escravarias que compõem a terceira faixa de tamanho decorre, em especial, da distribuição dos indivíduos com idades de 5 a 9 anos. De fato, se substituíssemos as cifras apresentadas na última coluna da Tabela 9 pelos porcentuais correlatos calculados tendo por base, como numerador, apenas tais indivíduos, obteríamos, respectivamente nas quatro faixas de tamanho aqui consideradas: $2,4 \%, 6,9 \%, 11,4 \%$ e $6,4 \% \cdot{ }^{28}$ Já a distribuição das crianças de 0 a 4 anos de idade, à exceção dos plantéis unitários, ${ }^{29}$ resulta em participações relativas bastante próximas - entre $7,5 \%$ e $7,9 \%$ - nas três outras faixas de tamanho.

27 Por exemplo, os plantéis com 2 a 5 escravos em São Cristóvão eram os que apresentavam a maior taxa de masculinidade entre as crianças de zero a 4 anos de idade: $45,7 \%$. É bastante plausível sugerir aí o resultado da presença da família escrava em plantéis formados por um casal de cativos em plena etapa reprodutiva.

28 Tomando como numerador, por sua vez, o número das crianças com 10 a 14 anos de idade, obteríamos os seguintes valores: $12,7 \%, 8,3 \%, 8,7 \%$ e $6,4 \%$. Salienta-se, neste caso, a inversão verificada no porcentual atinente aos plantéis unitários, decerto vinculada, em boa medida, ao fato deste intervalo etário apresentar-se bem mais sujeito às rupturas de laços familiares por conta de transações de compra (eventualmente, de filhos, relativamente mais baratos) e venda (eventualmente, de pais, relativamente mais valorizados).

29 Exceção esta, de resto, em nada surpreendente, uma vez que a presença da família escrava implicaria, na maior parte dos casos, a existência de plantéis com mais de um componente. Cabe observar que, por conta dessa "instabilidade" dos plantéis unitários sob o impacto das famílias e da reprodução escravas, excluímos a primeira faixa de tamanho na construção do Gráfico 4 a seguir (para tal faixa, a estimativa do índice de fecundidade geral resultou no valor de 43). 


\section{TABELA 9 - PARTICIPAÇÃO DAS CRIANÇAS NA POPULAÇÃO ES- CRAVA SEGUNDO FAIXAS DE TAMANHO DOS PLANTÉIS (FTP)}

\begin{tabular}{lccccc}
\hline FTP & $0-4(1)$ & $0-9(2)$ & total escravos(3) & {$[(1) /(3)] \times 100$} & {$[(2) /(3) \times 100]$} \\
\hline 1 & 2 & 5 & 126 & $1,6 \%$ & $4,0 \%$ \\
$2-5$ & 46 & 86 & 580 & $7,9 \%$ & $14,8 \%$ \\
$6-15$ & 49 & 127 & 643 & $7,6 \%$ & $19,8 \%$ \\
$16-32$ & 13 & 24 & 173 & $7,5 \%$ & $13,9 \%$ \\
Total & 110 & 242 & 1.522 & $7,2 \%$ & $15,9 \%$ \\
\hline
\end{tabular}

Esses valores da participação relativa - sobre os totais de cativos existentes em cada faixa de tamanho dos plantéis - das crianças com menos de 5 anos de idade, aliados à mais elevada taxa de masculinidade observada nas escravarias com mais de 15 componentes, influenciam as estimativas de índices de fecundidade geral representadas no Gráfico $4 .{ }^{30}$ Vale dizer, de um lado, ditas estimativas são calculadas levando em conta crianças cativas de uma faixa etária em que não se verificava o "excesso" de crianças percebido nos plantéis de 6 a 15 escravos; de outro, nas maiores posses escravas, havia um maior "risco de gravidez" para o segmento das mulheres em idade fértil dada a presença de um número relativo mais elevado de homens, fato esse que facilitaria a escolha de parceiros e a composição de casais no âmbito de um mesmo plantel. ${ }^{31}$ No Brasil, como sabido, as uniões estáveis davam-se, em

30 Lembremos que a taxa de fecundidade geral “... é o quociente, num determinado ano (j), entre o número de nascidos vivos e a população feminina dentro do periodo reprodutivo ou em idade fértil. Usualmente, considera-se idade fértil da população feminina a faixa de 15 a 49 anos." (CARVALHO, SAWYER \& RODRIGUES, 1994, p. 24). No nosso caso, na falta do informe acerca do número de nascidos vivos, a quantidade de crianças escravas de zero a 4 anos de idade conduz a um estimador mais grosseiro da fecundidade geral.

31 Embora apresentando esse "maior risco de gravidez", não se destaca, nos plantéis de 16 a 32 cativos comparados aos de 2 a 15 escravos, o porcentual das crianças de 0 a 4 anos de idade, uma vez que a supremacia numérica de homens implicava, ao fim e ao cabo, nas maiores escravarias, uma participação relativa mais modesta das mulheres em idade fértil. 
especial, nos plantéis mais numerosos; ${ }^{32}$ ademais, na maioria esmagadora dos casos, ambos os integrantes de cada casal pertenciam a um mesmo proprietário. ${ }^{33}$ Como resultado, não obstante as crianças - assim entendidos os indivíduos com menos de 15 anos de idade - se façam mais intensamente presentes nos plantéis com 6 a 15 elementos, são aqueles de 16 a 32 escravos os que apresentam a maior estimativa para a taxa geral de fecundidade. ${ }^{34}$

32 Por exemplo, entre outros, Robert Slenes, trabalhando com uma amostra de listas nominativas da matrícula de escravos de 1872, referentes ao município de Campinas, e computando os dados explicitamente em função do tamanho dos plantéis, obtém os seguintes resultados: nos plantéis formados por 1 a 9 escravos, $24 \%$ destes, com 15 anos ou mais, eram casados ou viúvos ( $22 \%$ dos homens e $26 \%$ das mulheres); nos plantéis com 10 ou mais escravos, tal porcentual alcança os $43 \%$ (30\% dos homens e $67 \%$ das mulheres; cf. SLENES, 1987, p. 225). Na mesma direção apontam os resultados encontrados para uma amostra das listas nominativas de habitantes da Vila de Lorena, em 1801, compulsadas por Costa, Slenes e Schwartz: do total de cativos casados ou viúvos, $13,2 \%$ encontravam-se nos plantéis de 1 a $4,23,3 \%$ nos de 5 a 9 e $63,5 \%$ nos de 10 a 41 escravos; nas mesmas faixas de tamanho dos plantéis, respectivamente, alinhavam-se $24,6 \%, 21,9 \%$ e $53,5 \%$ do total de escravos com 15 anos ou mais (cf. COSTA, SLENES \& SCHWARTZ, 1987, p. 252). Em ambos os trabalhos referidos, o aumento dos porcentuais de casados ou viúvos à medida que cresce o tamanho dos plantéis acompanhou variação no mesmo sentido ocorrida na razão de masculinidade.

33 Por exemplo, em Lorena, em 1801, no máximo 10,3\% dos casais seriam casos de enlaces envolvendo escravos de plantéis diferentes (cf. COSTA, SLENES \& SCHWARTZ, 1987, p. 257); em Campinas, em 1872, “... com exceção de algumas poucas pessoas que eram casadas com libertos, todos os escravos casados na amostra tinham cônjuges que pertenciam ao mesmo senhor.” (SLENES, 1987, p. 218). Em Santana de Parnaíba, Metcalf verifica, para o período 1720-1820, que 12,7\% dos casamentos de cativos reuniram escravos pertencentes a proprietários diferentes (cf. METCALF, 1983, p. 181). Já para a Bahia, observa Schwartz: "bavia, por exemplo, uma politica em geral não escrita mas amplamente praticada de restringir o universo social do cativo, confinando-o, quando possivel, ao perimetro do engenho, fazenda de cana ou unidade escravista. Tal politica limitava drasticamente as oportunidades familiares para os escravos, especialmente em propriedades menores, onde havia poucos parceiros disponiveis ou onde podiam ser parentes consangüineos. Em centenas de registros de batizados, casamentos e óbitos não encontrei nenhum escravo mencionado como casado com cativo de outro senhor. Não é difícil imaginar as complicaçôes que podiam surgir quando esse tipo de união ocorria: residências diferentes, separação forçada, conflitos sobre tratamen to humano e direitos de propriedade. Tais casamentos apresentavam problemas concretos para os escravos bem como para seus senhores, mas dado o desequilibrio na razão entre os sexos em muitas das propriedades do Recôncavo, os cativos que desejassem encontrar companheiros sem divida teriam aceito os problemas na falta de alternativas. A escolba, porém, ocorreu raramente, se é que alguma vez foi-lhes permitida.” (SCHWARTZ, 1988, p. 312).

34 Reproduz-se, também para São Cristóvão em 1870, outro resultado bastante recorrente na historiografia recente, qual seja, o cômputo de estimativas crescentes dos índices de fecundidade geral à medida que aumenta o tamanho dos plantéis de escravos. Todavia, a própria contradição aparente de que tratamos nesse parágrafo torna oportuna, por exemplo, a ressalva feita por Costa, Slenes e Schwartz em seu estudo sobre a família escrava em Lorena (1801): “... nos pequenos plantéis [ 1 a 4 cativos] contavam-se 396 crianças de 0 a 4 anos por grupo de 1.000 mulheres de 15 a 49 anos, na faixa intermediária de tamanho [5 a 9] encontravam-se $635 \mathrm{e}$, nos plantéis de maior porte [10 a 41], 792 crianças por grupo de 1.000 mulheres. Muito embora tais resultados pareçam sugestivos, não se deve esquecer que os mesmos podem estar enviesados. Assim, o indice referente à faixa de tamanho de 1 a 4 escravos estaria subestimado, pois como os pequenos plantéis formam-se - seja por compra, seja por variadas formas de doação (partilha em vida, herança etc.) - privilegiando cativos com idade mais elevada, poderiam estar sendo subtraidas de plantéis mais numerosos mulheres que nele deixaram sua prole. Esta mesma eventualidade traria como conseqüência a superestimação do indice pertinente aos plantéis maiores.” (COSTA, SLENES \& SCHWARTZ, 1987, p. 275). 


\section{GRÁFICO 4 - ESTIMATIVA PARA ÍNDICES DE FECUNDIDADE GE-} RAL, SEGUNDO FAIXAS DE TAMANHO DOS PLANTÉIS `

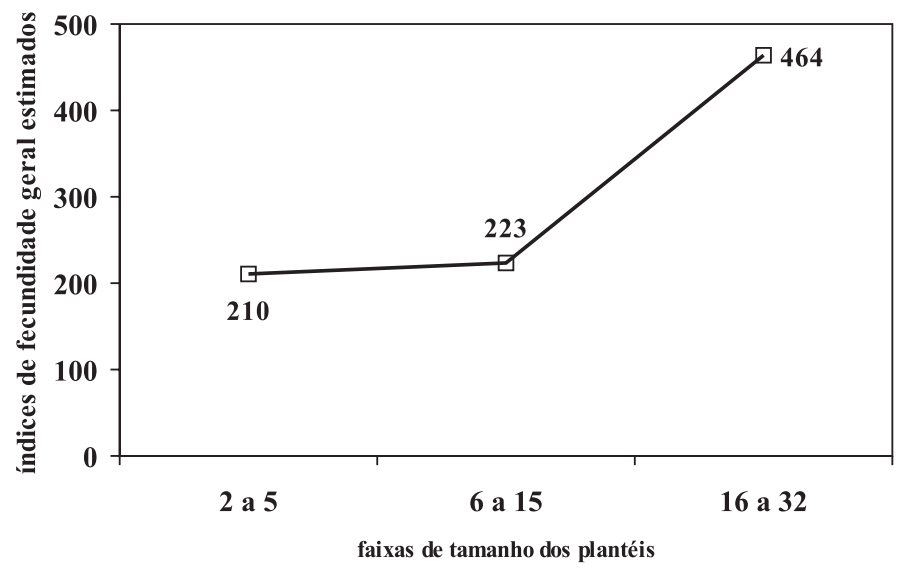

a Para cada faixa de tamanho dos plantéis, total de crianças de 0 a 4 anos dividido pelo total de mulheres de 15 a 49 anos, multiplicado por 1000 .

\section{ESTRUTURA DA POSSE DE ESCRAVOS EM SÃO CRISTÓVÃO: UMA ABORDAGEM COMPARATIVA}

Desde a publicação, em 1981, do trabalho pioneiro de Luna - Minas Gerais, escravos e senhores - têm sido inúmeros os estudos dedicados, de forma exclusiva ou não, ao tema da estrutura da posse de cativos. Em um primeiro momento as atenções estiveram concentradas no período que se abre no primeiro quartel do século dezoito e chega às décadas iniciais do dezenove. A disponibilidade de arrolamentos nominativos, produzidos com finalidades predominantemente fiscais ou censitárias, responde, em boa medida, por essa concentração. Os resultados alcançados, alguns dos quais serão apresentados nesta seção, para diversas localidades ou regiões e em variados anos, caracterizaram-se, em que pese a existência sempre possível de subenumeração, sobretudo quando se tratou de embasar a cobrança de impostos, pelo atributo da abrangência. Em outras palavras, os perfis observados, pelos diversos estudiosos do tema, da distribuição da propriedade escrava, 
levaram em conta, ao que tudo indica, o conjunto da população cativa, ou pelo menos dele não se afastaram em demasia. ${ }^{35}$

Mais recentemente houve o empenho de estender o exame da estrutura da posse de escravos para a segunda metade do Oitocentos, etapa crucial que se inaugurou com a extinção do tráfico transatlântico de africanos e na qual a questão servil caminhou no sentido da "solução final" posta pela abolição da escravatura. Contudo, para as décadas derradeiras da escravidão, não se pôde contar com fontes documentais primárias tão abundantes e ricas, para o estudo do tema em tela, quanto os arrolamentos nominativos utilizados para o período anterior. Os analistas, então, lançaram mão de outras fontes, entre as quais se destacaram os processos de inventários post mortem, as listas de matrículas de escravos (muitas das quais parte integrante dos referidos inventários) e as listas de classificação dos escravos para fins de emancipação. Alguns dos resultados deste esforço também serão apresentados nesta seção.

Assim sendo, processou-se a incorporação da segunda metade do século dezenove como objeto dos trabalhos sobre a estrutura da posse de cativos à custa, no entanto, da maior abrangência característica dos estudos centrados no intervalo temporal anterior. O caráter "amostral", no tocante ao enfoque da dita estrutura, é evidente no caso dos inventários e das listas de matrículas neles contidas. Por sua vez, nas listas de classificação, a perda da abrangência decorreu dos próprios critérios que instruíram sua confecção, estabelecidos no regulamento geral que disciplinou a execução da Lei do Ventre Livre, aprovado pelo Decreto 5.135, de 13 de novembro de 1872; pela aplicação desses critérios, deixavam-se de lado, ao menos parcialmente,

35 O receio do recrutamento compulsório, outra causa importante para uma eventual subenumeração, incidiria essencialmente sobre a população livre. Também poderia ocorrer a subestimação do número de escravos possuídos por escravistas detentores de várias propriedades, algumas das quais localizadas fora do perímetro abrangido pelo levantamento nominativo analisado; neste caso, os cativos alocados nestes últimos imóveis fugiriam aos nossos cômputos. Embora tal eventualidade nos pareça pouco freqüente, é forçoso reconhecer que, nestas situações, a subenumeração incidiria mais pesadamente sobre os plantéis pertencentes aos maiores escravistas e, por extensão, sobre as localidades cujo evolver se visse condicionado por um maior dinamismo econômico, propício à constituição/manutenção de escravarias de grande porte. 
as crianças com menos de 12 anos e, sobretudo, os adultos com mais de 50 anos de idade. ${ }^{36}$

Resta evidenciada, por conseguinte, uma vez mais, a importância do arrolamento da população de São Cristóvão realizado em abril de 1870 e fonte que embasa este artigo. Em certa medida, esse recenseamento permitiu-nos empreender o esforço acima mencionado sem incorrer nas perdas decorrentes das lacunas características dos demais documentos utilizados para a análise da estrutura da posse de escravos nas últimas décadas do período escravista brasileiro. Isto posto, passemos a confrontar os resultados encontrados para "nossa" paróquia fluminense com aqueles disponíveis na literatura sobre os padrões de distribuição da propriedade cativa no Brasil. De início, concentremos nossa atenção num conjunto de indicadores estatísticos - de posição (média, moda e mediana) e de concentração (índice de Gini) - atinentes aos proprietários de escravos.

As Tabelas 10 e 11 fornecem tais indicadores para a São Cristóvão de 1870, bem como para diversas outras localidades/regióes brasileiras em distintos anos compreendidos no período 1718-1836. Os informes sobre Minas Gerais, Bahia e São Paulo (aí incluído o Paraná) foram extraídos de estudos baseados em arrolamentos nominativos, a maior parte deles de caráter censitário, a exemplo dos conhecidos Maços de População, preservados no Arquivo do Estado de São Paulo, contendo uma coleção de recenseamentos afetos à província paulista e cobrindo boa parte da segunda metade do Setecentos e da primeira do século XIX. Foram também importantes, em especial para o caso de Minas Gerais, os róis de moradores efetuados tendo em vista a cobrança dos quintos, como na Vila de Pitangui, ou a cobrança da capitação dos escravos, como no Serro do Frio.

Examinando a Tabela 10, verificamos que os valores da média e do índice de Gini, disponíveis para a Bahia em 1816/7, mostram-se mais elevados do que os calculados para São Cristóvão. Isto não nos deve surpreender; afinal, da documentação trabalhada por Stuart Schwartz, constam os escravistas e os cativos de 165 engenhos existentes nos povoados de São Francisco e de

36 Cf. Colleção das leis do Império do Brasil de 1872, 1873, v. 2, p. 1053-1079. 
Santo Amaro, sendo esses engenhos "(...) os maiores e os melhores da capitania, e devem representar o limite superior da propriedade de escravos na Babia." (SCHWARTZ, 1983, p. 261). ${ }^{37}$ Da mesma forma, apresentam-se também superiores os indicadores referentes ao Oeste de São Paulo (Campinas e Itu em 1804, e as 6 localidades a que se referem os dados de 1829), uma vez mais tendo como elemento distintivo a cultura da cana-de-açúcar.

\section{TABELA 10 - INDICADORES ESTATÍSTICOS CONCERNENTES AOS ESCRAVISTAS DE SÃO CRISTÓVÃO (1870) E DE DIVER- SAS LOCALIDADES DE MINAS GERAIS (1718/1832), DA BAHIA (1816/7) E DO OESTE DE SÃO PAULO (1804/29)}

\begin{tabular}{|c|c|c|c|c|}
\hline Localidade, ano & Média $^{a}$ & Moda $^{a}$ & Mediana $^{a}$ & Ind.Gini \\
\hline Pitangui, $1718^{b}$ & 6,1 & 2 & 5 & 0,40 \\
\hline Pitangui, $1723^{\mathrm{b}}$ & 6,4 & 2 & 4 & 0,53 \\
\hline Serro do Frio, $1738^{b}$ & 4,6 & 1 & 2 & 0,57 \\
\hline Congonhas do Sabará, $1771^{b}$ & 5,6 & 1 & 3 & 0,55 \\
\hline Congonhas do Sabará, $1790^{b}$ & 4,5 & 1 & 2 & 0,54 \\
\hline Vila Rica, $1804^{b}$ & 3,7 & 1 & 2 & 0,50 \\
\hline Noroeste e Oeste de MG, $1831 / 2^{\circ}$ & 5,0 & nd & nd & nd \\
\hline Bahia, 1816/7 & 7,2 & nd & nd & 0,59 \\
\hline Campinas, $1804^{\mathrm{e}}$ & 7,1 & 1 & nd & 0,59 \\
\hline Itu, $1804^{\mathrm{e}}$ & 9,4 & 1 & nd & 0,59 \\
\hline Oeste Paulista, $1829^{f}$ & 11,3 & 1 & 4 & 0,65 \\
\hline São Cristóvão, 1870 & 3,8 & 1 & 3 & 0,46 \\
\hline
\end{tabular}

nd = informação não disponível.

${ }^{a}$ Os valores da tabela referem-se ao número de escravos possuídos por proprietário; ${ }^{\text {L }}$ LUNA (1981); ' PAIVA \& LIBBY (1985), localidades de Paracatu, Santo Antônio do Monte, Patos e Dores da Marmelada; ${ }^{\mathrm{d}}$ SCHWARTZ (1983), localidades diversas do Recôncavo Baiano; ${ }^{\mathrm{e}}$ LUNA \& COSTA (1983); ${ }^{\mathrm{f}}$ LUNA (1998), localidades de Campinas, Itapeva, Itu, Jundiaí, Mogi Mirim e Porto Feliz.

Como observa Luna,

"no Oeste Paulista o crescimento dos escravos alcançou 3,7\% ao ano entre 1777 e 1829 (...). Os números demonstram excep-

37 Vale observar que das listas remanescentes do recenseamento realizado entre setembro de 1816 e janeiro de 1817 constam mais de 4.600 proprietários, detentores, em seu conjunto, de pouco menos de 34.000 cativos, correspondentes a cerca de $23 \%$ do total da escravaria baiana (cf. SCHWARTZ, 1983, p. 260-261). 
cional expansão, particularmente no último quartel do século XVIII, pelo alargamento da atividade açucareira; mesmo em 1829, a cafeicultura ainda se mostrava pouco expressiva na região, que possuía importantes mícleos açucareiros como Campinas, Itu e Porto Feliz.” (LUNA, 1998, p. 106).

Quanto às localidades das Minas Gerais, nada podemos afirmar, por enquanto, sobre o Noroeste e o Oeste da província em inícios da década de 1830, para os quais obtivemos apenas a média. ${ }^{38}$ Dentre os demais casos, que representam fases distintas do evolver da atividade mineratória - a consolidação (Pitangui), a proximidade do apogeu (Serro do Frio), o início do esgotamento e a chegada da decadência (Congonhas do Sabará) e, por fim, o franco recesso (Vila Rica) -, os cômputos para São Cristóvão aproximamse em maior medida daqueles concernentes a esta última etapa. ${ }^{39}$ Além da decadência, salienta-se, também, o caráter urbano de Vila Rica:

"Identificamos quatro tipos básicos de estruturas populacionais: urbana, rural-mineradora, intermédia e rural de autoconsumo. Vila Rica, Passagem e Mariana [todas em 1804] enquadravam-se na primeira categoria. (...) estes múcleos caracterizavam-se por apresentarem, em termos gerais, os maiores porcentuais de livres e os menores valores para o numero médio de escravos, agregados e pessoas livres por domicilio. (...) Quanto aos setores classicamente definidos pelos economistas, observava-se modesta participação do primário, dominio do secundário e presença marcante dos serviços.” (COSTA, 1981, p. 177).

38 Voltaremos nossa atenção, novamente, para essas regiões mineiras mais adiante, quando compararmos as distribuiçỗes de escravistas e de escravos segundo diferentes faixas de tamanho dos plantéis.

39 'O quadro desta área mineira ao abrir-se o século XIX revelava-se desolador. Superada a febre' do ouro, a economia estagnara-se e apresentava-se franca recessão populacional. (...) A pobreza dos habitantes remanescentes e a existência de ruas inteiras quase abandonadas provocava imediata admiração dos visitantes a passar por Vila Rica. Das duas mil casas, quantidade considerável não estava ocupada (...). A população que alcançara, como atesta Saint-Hilaire, vinte mil pessoas, reduzira-se a oito milhares; tal quebra no numero de habitantes teria sido ainda maior não fosse Vila Rica a capital da capitania, centro administrativo e residência de um regimento.” (COSTA, 1979, p. 131-132). 
A Tabela 11 contempla, tão-somente, dados referentes ao território de São Paulo, à exceção do chamado "Oeste Paulista", inserido na tabela anterior. Com relação aos indicadores estatísticos atinentes a São Cristóvão, encontramos diferenças de maior monta na região do Vale do Paraíba, no litoral e na localidade mineratória de Apiaí. Nesta última, os valores mais discrepantes são os calculados para o último quarto do Setecentos e para 1835, vale dizer, tanto em momento próximo ao segundo surto de extração aurífera lá ocorrido - a jazida do Morro do Ouro foi oficialmente noticiada em 1775 -, como na etapa posterior, de decadência. ${ }^{40}$ Como observa Valentin,

"Diante da estagnação econômica vivenciada após o esgotamento do ouro, a manutenção desse padrão [de posse de cativos] associa-se aos fortes liames parentais entre os grandes escravistas de Apiai. O mecanismo de transmissão da posse através das heranças manteve parcela significativa desses proprietários ligados à vila e, ainda que os tamanhos das posses sofressem uma natural redução em função das divisões, a elevada freqüência dessas partilhas proporcionava um estoque considerável de cativos nas mãos dos novos proprietários, reiterando a desigual distribuição no restrito grupo de escravistas." (VALENTIN, 2001, p. 268).

No Vale do Paraíba e no litoral, as disparidades com respeito a São Cristóvão são menores no século XVIII, quando era relativamente menos pronunciada a presença da agroexportação. Tais discrepâncias crescem ao longo das décadas iniciais do Oitocentos e, além de nos remeterem uma vez mais ao desenvolvimento do cultivo da cana, parecem ter relação direta com a difusão da cafeicultura, atividade que, com relativa rapidez, conquista as maiores unidades produtivas em vários dos núcleos então existentes. Este o caso, por exemplo, da freguesia valeparaibana do Bananal:

"O periodo que se estende de 1817 a 1829 é marcado pela ampliação da disseminação da lavoura cafeeira na localidade. (...) diminui o peso relativo dos domicilios onde não se registra a presença de cativos e, entre os plantéis de escravos, perdem relativamente releváncia os formados por menos de 5 individu-

40 São dignas de nota as semelhanças verificadas entre o perfil da estrutura da posse de escravos em Apiái nas proximidades do primeiro surto mineratório, na década de 1730 , e aquele verificado, para o mesmo período, em diversas localidades das Minas Gerais (cf. VALENTIN, 2001, p. 49-67). 
os, observando-se uma elevação na média de cativos possuidos por proprietário. (...)

"Verifica-se, pois, em Bananal (...) uma tendência à concentração da propriedade escrava. Pari passu, o café (...) vai aos poucos tornando explícito seu entrosamento maior com uma agricultura dita de plantation.” (MOTTA, 1999, p. 373-374). ${ }^{41}$

Assim sendo, em São Paulo, os indicadores que mais se assemelham aos computados para São Cristóvão são aqueles atinentes às localidades mais apartadas das atividades mineratória e de agroexportação. Isto corresponde às regiões da Capital, do Paraná - cujo território, até 1853, esteve vinculado ao de São Paulo - e o Caminho do Sul. Na primeira, inserimos Mogi das Cruzes, cuja economia, na virada do século XVIII para o XIX, “(...) baseava-se em uma agricultura modesta, que abastecia os mercados locais. Dentre os produtos de exportação, incluiam-se: o milho, o feijão, o arroz, o algodão, o pano de algodão, a farinba de pau e aguardente.” (SANTOS, 2001, p. 71). Além desse direcionamento para o mercado interno, uma vez mais colabora com a semelhança dos indicadores o caráter urbano, pois os dados para o conjunto da região incorporam os informes da capital da província. Quanto ao Caminho do Sul, escreve Luna,

\section{"Uma modesta proporção de fogos com escravos e uma baixa} média de escravos por fogo explicavam o diminuto peso dos cativos no total de habitantes. [...] Sorocaba, importante centro de comércio de animais, apresentava os indicadores mais expressivos na região: porcentagem de fogos com escravos de 21,7\%; média de escravos por fogo de 1,2, e participação dos escravos na população, de 26,5\% em 1829, contra apenas $16 \%$ nos dois anos anteriores: 1777 e 1804.” (LUNA, 1998, p. 107). ${ }^{42}$

41 No litoral, em especial em sua porção norte, salienta-se o desenvolvimento açucareiro, sobretudo em São Sebastião, e cafeeiro, em particular em Ubatuba: "O sucesso da economia cafeeira provocou enormes modificaçóes na vida do Litoral Norte. Ubatuba passou por uma fase de significativo ange econômico e, especialmente na década de 1820 - anos de consolidação desta atividade - a taxa de crescimento da população escrava atingiu valores surpreendentes, ficando próxima dos $10 \%$ anuais; na década de 1830, por sua vez, esse crescimento continuou e, embora arrefecesse relativamente, continuaria sendo maior que o atingido em São Sebastião no ange açucareiro.” (FERNÁNDEZ, 1992, p. 301).

42 No tocante ao Paraná, os indicadores calculados por Gutiérrez Gallardo referem-se a três localidades litorâneas (Antonina, Guaratuba e Paranaguá), estando as demais situadas no planalto. No total, foram computados 4.976 escravos em 1804 e 5.662 em 1824; "os maiores proprietários de cativos residiam serra acima, nos Campos de Curitiba, Campos Gerais, nas cercanias de Castro, comercializando e criando gado vacum e cavalar, mas também cultivando mantimentos para sua alimentação." (GUTIÉRREZ GALLARDO, 1986, p. 27-28). 


\section{TABELA II - INDICADORES ESTATÍSTICOS CONCERNENTES AOS ESCRAVISTAS DE SÃO CRISTÓVÃO (1870) E DE DIVER- SAS LOCALIDADES DE SAOO PAULO (1735/1836) ${ }^{\mathrm{a}}$}

\begin{tabular}{|c|c|c|c|c|}
\hline Localidade, ano & Média $^{b}$ & Moda $^{b}$ & Mediana $^{b}$ & Ind.Gini \\
\hline 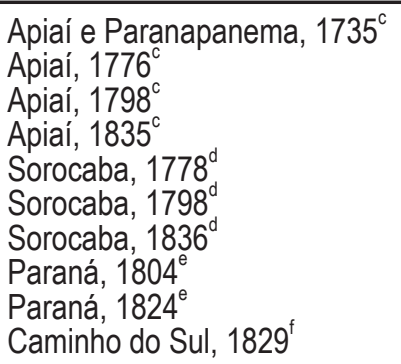 & $\begin{array}{r}4,5 \\
9,3 \\
11,3 \\
8,0 \\
4,6 \\
5,1 \\
5,7 \\
5,6 \\
5,0 \\
4,6\end{array}$ & $\begin{array}{l}1 \\
1 \\
1 \\
1 \\
1 \\
1 \\
1 \\
1 \\
1 \\
1\end{array}$ & $\begin{array}{l}3 \\
2 \\
6 \\
3 \\
2 \\
3 \\
3 \\
3 \\
3 \\
3\end{array}$ & $\begin{array}{l}0,51 \\
0,70 \\
0,63 \\
0,62 \\
0,53 \\
0,55 \\
0,58 \\
0,56 \\
0,53 \\
0,52\end{array}$ \\
\hline $\begin{array}{l}\text { Ubatuba, } 1778^{g} \\
\text { Ubatuba, } 1798^{g} \\
\text { Ubatuba, } 1836^{g} \\
\text { Litoral, } 1829^{\mathrm{h}}\end{array}$ & $\begin{array}{l}5,7 \\
4,9 \\
8,5 \\
6,2\end{array}$ & $\begin{array}{l}1 \\
1 \\
1 \\
1\end{array}$ & $\begin{array}{l}3 \\
3 \\
4 \\
3\end{array}$ & $\begin{array}{l}0,56 \\
0,55 \\
0,63 \\
0,57\end{array}$ \\
\hline $\begin{array}{l}\text { Mogi das Cruzes, } 1777^{i} \\
\text { Mogi das Cruzes, } 1801^{i} \\
\text { Mogi das Cruzes, } 1829^{i} \\
\text { Capital, } 1829^{j}\end{array}$ & $\begin{array}{l}4,3 \\
5,2 \\
4,7 \\
5,0\end{array}$ & $\begin{array}{l}1 \\
1 \\
1 \\
1\end{array}$ & $\begin{array}{l}3 \\
3 \\
3 \\
3\end{array}$ & $\begin{array}{l}0,49 \\
0,51 \\
0,52 \\
0,53\end{array}$ \\
\hline $\begin{array}{l}\text { Taubaté, } 1774^{\mathrm{k}} \\
{\text { Taubaté, } 1798^{\mathrm{k}}}^{\mathrm{k}} \\
{\text { Taubaté, } 1835^{\mathrm{k}}} \\
{\text { Lorena, } 1801^{1}}^{\mathrm{m}} \\
\text { Bananal, } 1817^{\mathrm{m}} \\
\text { Bananal, } 1829^{\mathrm{m}} \\
\text { Vale do Paraíba, } 1829^{\mathrm{n}}\end{array}$ & $\begin{array}{r}4,7 \\
4,7 \\
5,1 \\
5,6 \\
8,4 \\
11,7 \\
7,5\end{array}$ & $\begin{array}{r}\text { nd } \\
\text { nd } \\
\text { nd } \\
1 \\
1 \\
1 \\
1\end{array}$ & $\begin{array}{l}\text { nd } \\
\text { nd } \\
\text { nd } \\
3 \\
4 \\
5 \\
4\end{array}$ & $\begin{array}{l}0,53 \\
0,50 \\
0,48 \\
0,54 \\
0,65 \\
0,66 \\
0,60\end{array}$ \\
\hline São Cristóvão, 1870 & 3,8 & 1 & 3 & 0,46 \\
\hline
\end{tabular}

nd = informação não disponível.

${ }^{a}$ No período considerado nesta tabela, e até 1853, a região paranaense integrava a Capitania, depois Província de São Paulo; ${ }^{b}$ Os valores da tabela referem-se ao número de escravos possuídos por proprietário; ${ }^{\mathrm{c}}$ VALENTIN (2001); ${ }^{\mathrm{d}}$ LUNA (1986); ${ }^{\mathrm{e}}$ GUTIÉRREZ GALLARDO (1986), localidades de Antonina, Guaratuba, Paranaguá, Castro, Curitiba, Lapa, Palmeira, Ponta Grossa e São José dos Pinhais; ${ }^{\mathrm{f}}$ LUNA (1998), localidades de Curitiba, Itapetininga e Sorocaba; ${ }^{\mathrm{g}}$ FERNÁNDEZ (1992);

${ }^{\text {h }}$ LUNA (1998), localidades de Cananéia, Iguape, Santos e São Sebastião; ${ }^{i}$ SANTOS (2001);

j LUNA (1998), localidades de Atibaia, Cotia, Guarulhos, Mogi das Cruzes e São Paulo; ${ }^{\text {k }}$ RANGEL (1990); ${ }^{1}$ COSTA \& NOZOE (1989); ${ }^{\mathrm{m}}$ MOTTA (1999); ${ }^{\mathrm{n}}$ LUNA (1998), localidades de Areias, Cunha, Guaratinguetá, Jacareí, Lorena, Pindamonhangaba e São Luís do Paraitinga.

Os informes dispostos na Tabela 12 permitem-nos comparar a estrutura da posse de escravos de São Cristóvão com as vigentes, na segunda metade do Oitocentos, em várias outras localidades brasileiras. Nenhum dos estudos nos quais tais informes foram obtidos baseou-se em arrolamentos nominativos semelhantes ao que fundamentou o cálculo dos indicadores estatísticos referentes à "nossa" freguesia fluminense; todos eles, com as inerentes limita- 
ções às quais nos referimos anteriormente, lançaram mão seja de processos de inventários post mortem, seja de listas de classificação de escravos elaboradas tendo em vista a regulamentação do Fundo de Emancipação. Além disso, cumpre notar que apenas para o trabalho de Zélia M. C. de Mello acerca do município de São Paulo conseguimos inferir todos os indicadores estatísticos ora contemplados; a média de cativos por proprietário foi determinada para todas as localidades, o índice de Gini para a maior parte delas, restringindose o cálculo da moda aos casos de São Paulo e de Sergipe.

\section{TABELA 12 - INDICADORES ESTATÍSTICOS CONCERNENTES AOS ESCRAVISTAS DE SÃO CRISTÓVÃO (1870) E DE DIVER- SAS OUTRAS LOCALIDADES BRASILEIRAS (EM TORNO A 1870)}

\begin{tabular}{|c|c|c|c|c|}
\hline Localidade, ano & Média $^{a}$ & Moda $^{a}$ & Mediana $^{a}$ & Ind.Gini \\
\hline $\begin{array}{l}\text { Mariana, MG, } 1860 / 69^{b} \\
\text { Mariana, MG, } 1870 / 79^{b}\end{array}$ & $\begin{array}{r}10,8 \\
9,3\end{array}$ & $\begin{array}{l}\text { nd } \\
\text { nd }\end{array}$ & $\begin{array}{l}\text { nd } \\
\text { nd }\end{array}$ & $\begin{array}{l}0,61 \\
0,56\end{array}$ \\
\hline $\begin{array}{l}\text { Magé, RJ, } 1860 / 66^{c} \\
\text { Magé, RJ, } 1870 / 76^{\circ}\end{array}$ & $\begin{array}{r}10,3 \\
7,0\end{array}$ & $\begin{array}{l}\text { nd } \\
\text { nd }\end{array}$ & $\begin{array}{l}\text { nd } \\
\text { nd }\end{array}$ & $\begin{array}{l}\text { nd } \\
\text { nd }\end{array}$ \\
\hline $\begin{array}{l}\text { Estância, SE, } 1850 / 69^{d} \\
\text { Estância, SE, } 1870 / 88^{d} \\
\text { Sergipe, } 1873 / 75^{\mathrm{e}}\end{array}$ & $\begin{array}{l}7,7 \\
5,2 \\
3,8\end{array}$ & $\begin{array}{r}\text { nd } \\
\text { nd } \\
1\end{array}$ & $\begin{array}{l}\text { nd } \\
\text { nd } \\
\text { nd }\end{array}$ & $\begin{array}{l}\text { nd } \\
\text { nd } \\
\text { nd }\end{array}$ \\
\hline $\begin{array}{l}\text { Oeiras, PI, } 1875^{f} \\
\text { Teresina, PI, } 1875^{f}\end{array}$ & $\begin{array}{l}4,4 \\
5,2\end{array}$ & $\begin{array}{l}\text { nd } \\
\text { nd }\end{array}$ & $\begin{array}{l}\text { nd } \\
\text { nd }\end{array}$ & $\begin{array}{l}0,53 \\
0,56\end{array}$ \\
\hline $\begin{array}{l}\text { São Paulo, SP, } 1861 / 71^{9} \\
\text { São Paulo, SP, } 1872 / 80^{9} \\
\text { Lorena, SP, } 1851 / 79^{h} \\
\text { Lorena e Cruzeiro, SP, } 1874^{i} \\
\text { Bananal, SP, } 1873^{i} \\
\text { São José dos Campos, SP, } 1874^{i} \\
\text { Taubaté, SP, } 1872^{i}\end{array}$ & $\begin{array}{r}8,9 \\
8,3 \\
18,7 \\
6,1 \\
15,2 \\
4,6 \\
6,3\end{array}$ & $\begin{array}{l}1 \\
1 \\
\text { nd } \\
\text { nd } \\
\text { nd } \\
\text { nd } \\
\text { nd }\end{array}$ & $\begin{array}{l}4 \\
3 \\
\text { nd } \\
\text { nd } \\
\text { nd } \\
\text { nd } \\
\text { nd }\end{array}$ & $\begin{array}{l}0,82 \\
0,88 \\
0,60 \\
0,61 \\
0,76 \\
0,57 \\
0,64\end{array}$ \\
\hline São Cristóvão, 1870 & 3,8 & 1 & 3 & 0,46 \\
\hline
\end{tabular}

nd = informação não disponível.

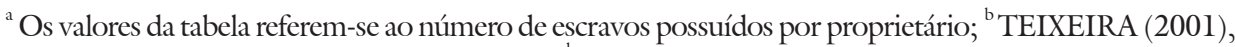
inventários; ${ }^{\mathrm{c}}$ SAMPAIO (1994), inventários; ${ }^{\mathrm{d}}$ PASSOS SUBRINHO (2001), inventários; ${ }^{\mathrm{e}}$ PASSOS SUBRINHO (2001), listas de classificação dos municípios de Campos, Simão Dias, Riachão, Ilha do Ouro, Propriá, Vila Nova, Itabaianinha, Capela, Laranjeiras, Japaratuba, Rosário e Maurim; ${ }^{\mathrm{f}}$ MARCONDES \& FALCI (2001), listas de classificação; ${ }^{\mathrm{g}}$ MELLO (1985), inventários; ${ }^{\mathrm{h}}$ MARCONDES (1998), inventários; ${ }^{\text {i }}$ MARCONDES (2000), listas de classificação.

Observando os indicadores disponíveis, a maior semelhança com São Cristóvão parece radicar nos 14 municípios sergipanos analisados por Passos 
Subrinho, que assim descreve o perfil encontrado para a estrutura da posse de cativos:

"Na primeira metade da década de 1870, em Sergipe, a propriedade escrava estava fortemente disseminada pelas diversas atividades econômicas, regiões e segmentos sociais. Havia uma ampla base social de proprietários de escravos e os grandes plantéis eram os de acima de uma dezena de escravos, os quais não chegavam a representar mais de $10 \%$ dos plantéis, controlando, contudo, quase a metade do total de escravos. $O$ plantel de um único escravo era, em geral, o plantel modal e os pequenos plantéis eram fortemente majoritários. Quanto ao controle da escravaria, tal feito não se repetia, havendo concentração dos escravos entre os médios e grandes plantéis." (PASSOS SUBRINHO, 2001, p. 13). ${ }^{43}$

As médias fornecidas no mesmo trabalho, atinentes ao município sergipano de Estância (um dos "principais núcleos da agro-indústria açucareira da [Zona da] Mata Sul”, cf. PASSOS SUBRINHO, 2000, p. 79), desta feita calculadas a partir dos inventários, mantêm-se relativamente próximas ao indicador de São Cristóvão, em especial aquela concernente ao período $1870 / 88 .^{44}$

Essa proximidade relativa é igualmente observada nos indicadores afetos às duas localidades piauienses estudadas por Marcondes e Falci, sobretudo no caso de Oeiras. Tanto este último município, com 1.848 escravos listados,

43 As 14 listas de classificação computadas pelo autor traziam informações sobre 10.554 cativos, os quais se distribuíam por 2.761 plantéis, desde os unitários até a maior escravaria, com 87 indivíduos (cf. PASSOS SUBRINHO, 2001, p. 5). Convém ressalvar, como o faz o próprio autor, dois bons motivos para considerarmos com cautela esses resultados agregados para a Província de Sergipe: "a) variaçôes significativas na qualidade das amostras, desde as listas que se aproximam do universo dos escravos matriculados, em 1873, e residentes nos respectivos municipios em anos subseqüuentes, até amostras muito pequenas do universo dos escravos matriculados, elaboradas segundo as regras da classificação de escravos, não reconstituindo plantéis de escravos e não incluindo boa parte dos prováveis proprietários (...); b) os municípios para os quais encontramos listas de classificação de escravos estão localizados em diferentes micro-regiôes da Provincia, as quais representam estruturas sócio-econômicas distintas." (PASSOS SUBRINHO, 2001, p. 6).

44 Nos inventários examinados pelo autor em questão, atinentes ao período de 1850 a 1888 , havia um total de 2.233 escravos - 503 deles nos processos referentes ao subperíodo 1870/88 -, os quais se distribuíam entre 322 proprietários -97 deles inventariados no intervalo 1870/88 (cf. PASSOS SUBRINHO, 2001, p. 11). 
como Teresina, com 2.770, marcavam-se, em meados da década de 1870, por uma atividade econômica mais direcionada para o mercado interno, ${ }^{45}$ pela distribuição sexual equilibrada da população cativa e pela significativa presença dos escravos com menos de 15 anos de idade: 36,5\% dos cativos em Teresina e 39,8\% em Oeiras (cf. MARCONDES \& FALCI, 2001, p. 9-11).

No que diz respeito às localidades paulistas contempladas na Tabela 12, os indicadores mais semelhantes aos de São Cristóvão são aqueles calculados para São José dos Campos. De fato, no conjunto, estudado por Marcondes, das listas de classificação referentes a municípios situados na Região do Vale do Paraíba, “(...) São José dos Campos revelava um comportamento muito mais acanbado em termos da propriedade escrava, pois seu número médio de cativos e indice de Gini eram significativamente inferiores às demais." (MARCONDES, 2001, p. 22). ${ }^{46}$ Até mesmo a capital da Província, objeto do trabalho de Mello, apresenta valores da média de escravos por proprietário e do índice de Gini bastante superiores aos de São Cristóvão. Nesse caso, claramente, a disparidade das fontes utilizadas - o arrolamento nominativo de São Cristóvão versus os inventários de São Paulo - responde pelas diferenças observadas. ${ }^{47}$ Ainda que residentes em São Paulo, muitos dos inventariados

45 Não obstante essa prevalência da produção para o mercado interno, foi importante também, por exemplo, o envolvimento do Piauí no surto algodoeiro decorrente da guerra civil norte-americana, colocando-se Teresina entre os principais municípios produtores (cf. MARCONDES \& FALCI, 2001, p. 7).

46 Em que pese o fato de o ritmo mais intenso de crescimento da produção cafeeira, entre $1854 \mathrm{e}$ 1886, dentre as localidades do Vale do Paraíba, ter-se verificado exatamente em São José. Um indício para a supressão desse paradoxo infere-se da citação, feita por Marcondes, da Dissertação de Mestrado de Maria Aparecida C. R. Pappali. Esta autora, escreve Marcondes, “(...) ao trabalhar com 30 inventários (...) entre 1870 e 1888, observou: A documentação consultada indica que a cidade de São José dos Campos vinha se constituindo, e formando seus cafezais, pela presença bastante numerosa de pequenos e médios lavradores. Sitiantes e 'meeiros' povoavam aquelas paragens em grande quantidade. (...) Provavelmente seja essa uma peculiaridade das lavouras de café de São José dos Campos de finais do século XIX. Mesmo as maiores fazendas não deveriam ter as dimensões que as grandes fazendas dos barôes do café tiveram nos áureos tempos da cafeicultura no Vale do Paraíba Paulista'.” (MARCONDES, 2001, p. 6). Os totais de cativos presentes nas listas trabalhadas por Marcondes alçaram-se a 2.245, 7.536, 1.110 e 4.165, respectivamente, em Lorena e Cruzeiro, Bananal, São José dos Campos e Taubaté (cf. MARCONDES, 2001, p. 9).

47 No conjunto dos processos compulsados por Zélia Mello, referentes ao período 1845/95, foram computados 309 escravistas, detentores de 2.936 cativos (cf. MELLO, 1985, p. 77). 
possuíam patrimônio que se espraiava por toda a província, em especial no caso de grandes fazendeiros de café. ${ }^{48}$

Também se baseiam em inventários os estudos de Teixeira e de Sampaio, respectivamente, sobre Mariana, nas Minas Gerais, e sobre Magé, esta última localizada, à semelhança de São Cristóvão, na província do Rio de Janeiro. ${ }^{49}$ As discrepâncias, com respeito aos indicadores de São Cristóvão, são maiores no caso de Mariana e, tanto para Mariana como para Magé, maiores na década de 1860 vis-à-vis à de 1870. Nas palavras de Teixeira,

\begin{abstract}
"Desde o declínio da mineração, Mariana esteve integrada à economia voltada para a produção de subsistência e o abastecimento do mercado inter e intraprovincial. O garimpo, em menor escala, manteve-se presente, mas aparecia conjugado às atividades agricola, pecuária, comercial e manufatureira. Através dos inventários post mortem examinados neste trabaIho, podemos aventar que, pelo menos até o final do século XIX, Mariana destacava-se economicamente pela diversificação das suas atividades.” (TEIXEIRA, 2001, p. 136).
\end{abstract}

Em Magé, por sua vez, uma economia centrada na produção de alimentos processava-se num contexto de contundente hierarquização social. Essa hierarquização, como salienta Sampaio,

“(..) significava uma diferenciação não só em termos do ta-
manho das fortunas, como em relação à própria orientação
econômica das unidades produtivas, divididas basicamente (...)
em dois tipos principais, no que diz respeito à forma de explo-

48 O exemplo dos imóveis é ilustrativo: “(...) há individuos com atividades e propriedades tipicamente urbanas; há os que possuem imóveis na cidade e nos arredores ou somente nos arredores e, portanto, podem desenvolver atividades de autoconsumo, subsistência ou ligadas à circulação e portanto 'mais rurais'. Há também proprietários de fazendas no interior, ou seja, ainda que moradores em São Paulo, seu comando de riqueza ultrapassa os limites geográficos da cidade.” (MELLO, 1985, p. 76). Sobre esta questão, ver o comentário feito na nota 35.

49 Nos inventários de Mariana, foram computados 1.143 cativos nos anos de 1860/69, e 1.101 no intervalo 1870/79; em Magé, foram 432 escravos na década de 1860 (1860/66) e 190 no decênio subseqüente (1870/76). Cf. TEIXEIRA (2001, p. 74), e SAMPAIO (1994, p. 137). 


\section{ração e à lógica econômica: a fazenda mercantil e a unidade camponesa.” (SAMPAIO, 1994, p. 174).}

Em suma, considerados os indicadores estatísticos concernentes à segunda metade do Oitocentos, os informes de São Cristóvão mostram-se mais apartados daqueles calculados para as localidades paulistas, à exceção de São José dos Campos, bem como dos de Mariana e Magé. A cafeicultura, de um lado, e, de outro, a produção de alimentos direcionada de modo precípuo para o mercado, conformam o pano de fundo a justificar essas dessemelhanças. ${ }^{50}$ As maiores similitudes, por seu turno, são encontradas nos indicadores atinentes ao Sergipe e ao Piauí, onde a produção de subsistência também predominaria, muito embora igualmente se fizessem presentes os gêneros de exportação, a exemplo do açúcar e do algodão.

Todavia, parecenças e disparidades fundamentadas, na maior parte dos casos, tão-somente na média, como o são os que integram a Tabela 12, e mesmo quando disponíveis os demais indicadores contemplados (moda, mediana e índice de Gini), como ocorrido para quase todas as situações dispostas nas Tabelas 10 e 11, demandam um exame um pouco mais aprofundado. Para tanto, avancemos nossa comparação a partir das distribuições, de escravistas e de cativos, segundo distintas faixas de tamanho dos plantéis, fornecidas nos Gráficos de números 5 a 12 a seguir. Com o intuito de facilitar o cotejo entre as diversas localidades selecionadas, procedemos ao remanejamento das faixas de tamanho anteriormente estabelecidas para São Cristóvão. ${ }^{51}$

50 Como observa Sampaio sobre a hierarquização social em Magé, "esta hierarquização tinha um caráter excludente, pois representava também o controle, por uma minuscula elite, da maior parte da riqueza gerada por tal sociedade, principalmente daqueles fatores que lhe eram mais importantes: os bens de raiz (principalmente a terra) e os escravos. (...) Chamou-nos especialmente a atenção o fato de que esta concentração da riqueza era muito semelhante à encontrada em áreas agroexportadoras, apesar das diferenças em termos de tamanhos de fortuna (...).” (SAMPAIO, 1994, p. 175).

51 Trabalhamos com os recortes indicados a seguir. Gráficos 5 e 6: 1 a 5, 6 a 10 e 11 ou + escravos. Gráficos 7 e 8: 1 a 3, 4 a 9 e 10 ou mais cativos. Gráficos 9, 10, 11 e 12: 1 a 4, 5 a 9 e 10 ou + escravos. Não obstante tais remanejamentos, nos dois primeiros e nos dois últimos dos gráficos mencionados não foi possível uma total identidade entre as faixas de tamanho para todas as localidades contempladas. Na segmentação privilegiada na seção anterior (cf. Tabela 1 ), vale lembrar, demos destaque às pessoas que estavam a ingressar na categoria de escravistas (1 cativo); aos detentores de plantéis em que poderiam comparecer famílias escravas em formação e/ou que apresentavam porte modesto ( 2 a 5 mancípios); aos proprietários de porte médio (6 a 15 escravos), os quais certamente achavam-se vinculados a atividades econômicas relativamente exigentes em mão-de-obra e com maior expressividade no tocante à escala de produção de bens ou serviços colocada sob sua direção, e , por fim, aos que poderíamos tomar, tendo-se em conta os padrốes brasileiros, como grandes escravistas (16 ou mais cativos). 


\section{GRÁFICO 5 - DISTRIBUIÇÃO DOS ESCRAVISTAS SEGUNDO EAIXAS DE TAMANHO DOS PLANTÉIS}

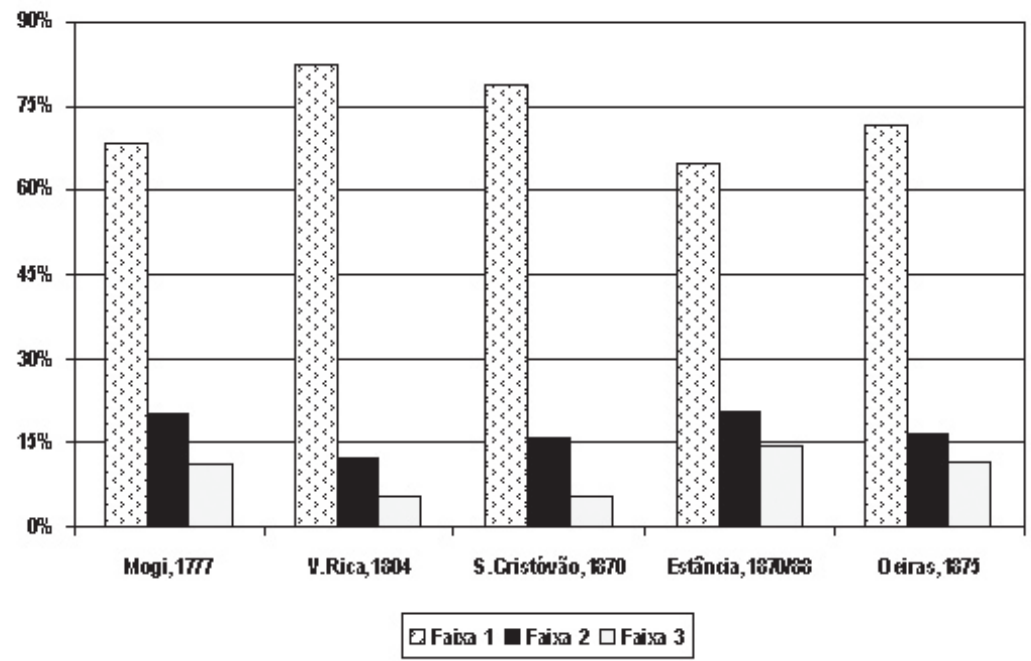

Faixa 1 = 1 a 4 escravos em Mogi, Estância e Oeiras; 1 a 5 em Vila Rica e São Cristóvão.

Faixa 2 = 5 a 9 escravos em Mogi, Estância e Oeiras; 6 a 10 em Vila Rica e São Cristóvão.

Faixa 3 = 10 ou + escravos em Mogi, Estância e Oeiras; 11 ou + em Vila Rica e São Cristóvão.

Nos dois primeiros gráficos mencionados, apresentamos as ditas distribuições para São Cristóvão, em 1870, bem como para quatro outras localidades cujos indicadores estatísticos, acima examinados, aproximavam-se dos computados para a freguesia fluminense. Duas dessas localidades foram escolhidas dentre as arroladas nas Tabelas 10 e 11 ; vale dizer, são casos referentes ao século XVIII e à primeira metade do Oitocentos. As outras duas foram selecionadas dentre as integrantes da Tabela 12, concernentes, pois, à segunda metade do século XIX.

As semelhanças, no que concerne às distribuições dos proprietários de cativos (Gráfico 5), são muito nítidas, e seriam ainda mais pronunciadas se as faixas fossem exatamente as mesmas em todos os cinco casos descritos. ${ }^{52}$

52 De fato, a faixa de tamanho de 1 a 4 cativos congregava 72,3\% dos proprietários de São Cristóvão; outros 21,4\% possuíam plantéis com 5 a 9 escravos e 6,3\% detinham 10 ou mais cativos. Os porcentuais correlatos, concernentes às três faixas representadas no Gráfico 5, igualam-se, respectivamente, a $78,6 \%, 15,9 \%$ e $5,5 \%$. 
Verificamos que os menores escravistas perfizeram entre cerca de dois terços (Estância, 1870/88) e mais de quatro quintos do total (Vila Rica, 1804), enquanto os detentores dos plantéis de maior tamanho corresponderam sempre a menos de $15 \%$ do conjunto.

Consideradas as distribuições dos escravos (Gráfico 6), as proximidades são menos marcadas. ${ }^{53}$ Podemos aventar dois movimentos, os quais, possivelmente, estariam a contribuir para a especificidade de São Cristóvão. Ambos são tributários do evolver da escravidão no período pós-extinção do tráfico transatlântico de cativos. Um deles, a tendência à concentração da posse escrava nas mãos dos maiores proprietários, à medida que o somatório da população cativa brasileira declinava significativamente. Esse movimento conduz ao que, por exemplo, Hebe M. M. de Castro, em seu estudo sobre o sudeste do Brasil, denominou "hegemonia da vida coletiva nos grandes plantéis", na segunda metade do século XIX (cf. CASTRO, 1995, p. 138). Ainda que os resultados analisados neste artigo patenteiem a oportunidade de nuançar, em alguma medida, a aludida expressão ${ }^{54}$ - pois são claras as indicações da permanência de uma escravidão disseminada nas distintas regiões, nas variadas atividades econômicas e pelos diversos portes de escravistas -, a tendência referida é inegável.

53 Afirmativa que se mantém mesmo quando igualamos as faixas de tamanho de São Cristóvão às consideradas pelos estudiosos de Mogi das Cruzes, Estância e Oeiras. Assim, nos plantéis com l a 4,5 a 9 e 10 ou mais cativos viviam, respectivamente, $38,2 \%, 37,2 \%$ e $24,6 \%$ dos escravos arrolados em São Cristóvão. Os porcentuais correlatos, concernentes às três faixas representadas no Gráfico 6, alçaram-se, respectivamente, a 46,4\%, 30,9\% e 22,7\%.

54 Procedimento que se mantém oportuno, vale frisar, mesmo se nos restringirmos aos resultados respeitantes ao sudeste escravista. 


\section{GRÁFICO 6 - DISTRIBUIÇÃO DOS ESCRAVOS SEGUNDO FAIXAS DE TAMANHO DOS PLANTÉIS}

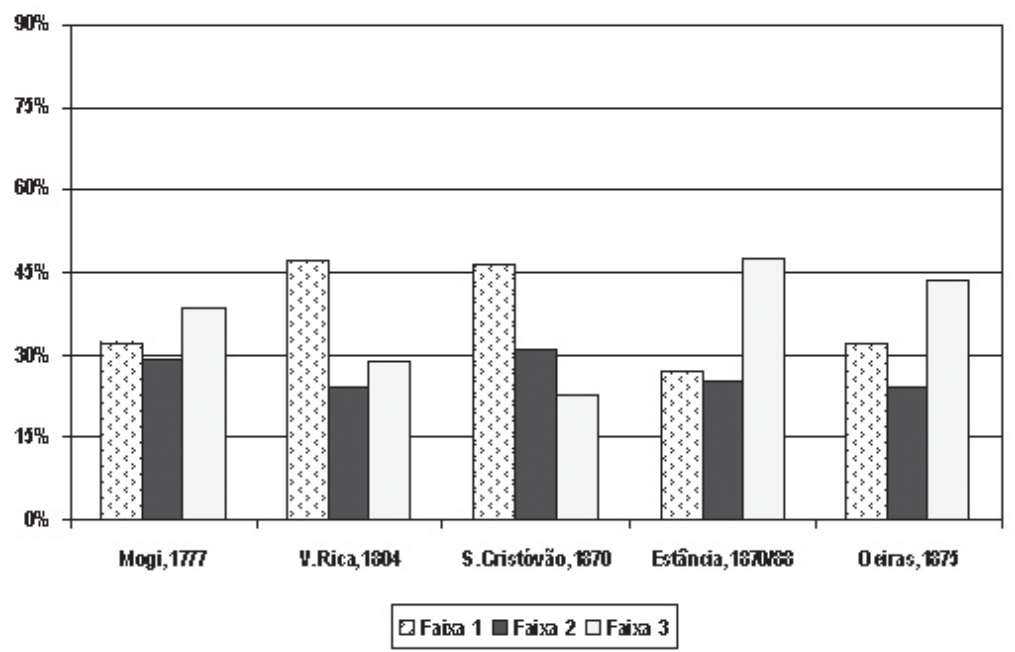

Faixa 1 = 1 a 4 escravos em Mogi, Estância e Oeiras; 1 a 5 em Vila Rica e São Cristóvão. Faixa 2 = 5 a 9 escravos em Mogi, Estância e Oeiras; 6 a 10 em Vila Rica e São Cristóvão. Faixa 3 = 10 ou + escravos em Mogi, Estância e Oeiras; 11 ou + em Vila Rica e São Cristóvão.

O segundo movimento, imbricado com o primeiro, diz respeito ao possível deslocamento de cativos do meio urbano para o meio rural, deslocamento este ao qual já nos referimos em seções anteriores deste artigo. Dessa forma, a diminuição da escravaria, aliada à demanda de mão-de-obra proveniente das atividades produtivas no campo, talvez responda pela menor presença relativa, em São Cristóvão, dos escravos alocados nos plantéis de maior tamanho, seja vis-à-vis Mogi (1777) e Vila Rica (1804), seja, sobretudo, em comparação a Estância (1870/88) e Oeiras (1875). 


\section{GRÁFICO 7 - DISTRIBUIÇÃO DOS ESCRAVISTAS SEGUNDO FAIXAS DE TAMANHO DOS PLANTÉIS (SÃO CRISTÓVÃO, 1870; DIVERSAS LOCALIDADES DO SERGIPE, 1873/75)}

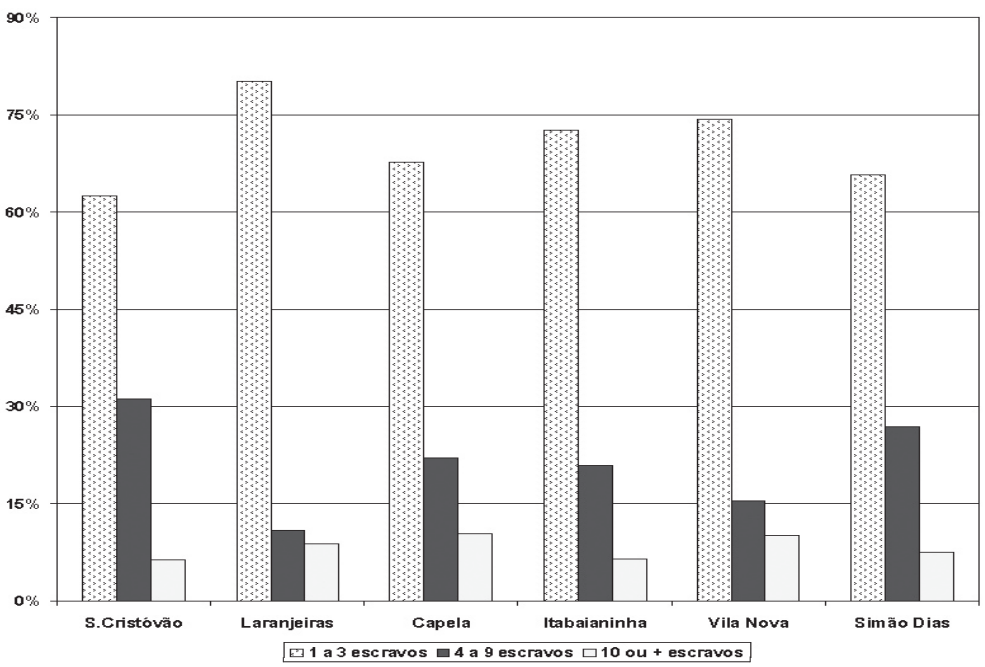

Nos Gráficos 7 e 8, outros exemplos da distribuição dos escravistas e dos cativos de acordo com diferentes faixas de tamanho dos plantéis, todos eles atinentes à província de Sergipe na segunda metade do século XIX, corroboram, mesmo num conjunto de localidades cujo perfil da estrutura da posse de escravos mostrou-se relativamente próximo, a presença inescapável de disparidades que refletem, em boa medida, panos de fundo socioeconômicos diferenciados. ${ }^{55}$ Tais exemplos abrangem cinco municípios situados em dis-

55 Com o que se corrobora a justeza do item b da ressalva feita por Passos Subrinho, transcrita na nota 43. Para o caso de Pernambuco, Versiani e Vergolino, com fundamento em 323 inventários de escravistas do Agreste e 169 do Sertão, referentes ao período de 1770 a 1887 , confrontam as características da posse de escravos nessas duas regiões. A primeira, com "(...) uma estrutura produtiva voltada essencialmente à produção agricola alimentar (tanto para autoconsumo quanto para abastecimento da zona litorânea), ao cultivo do algodão e à criação de gado, atividades muitas vezes desenvolvidas simultaneamente numa mesma propriedade. (...) e o Sertão semi-árido, onde predominava a atividade criatória." (VERSIANI \& VERGOLINO, 2001, p. 2). Os resultados das distribuições de escravistas e de escravos - aos quais não dispensamos o mesmo tratamento gráfico dado às localidades sergipanas tendo em vista a amplitude do intervalo temporal considerado -, são os que se seguem. Escravistas do Agreste: $54,8 \%$ com 1 a 5 cativos, $27,2 \%$ com 6 a 10 e $18,0 \%$ com 11 ou mais; escravistas do Sertão: respectivamente, $52,7 \%, 29,6 \%$ e $17,7 \%$. Escravos do Agreste: $16,4 \%$ nos plantéis com 5 ou menos escravos, $25,3 \%$ nas escravarias com 6 a 10 cativos e 58,3\% nos maiores plantéis; escravos do Sertão: respectivamente: $21,9 \%, 34,3 \%$ e $43,8 \%$ (cf. VERSIANI \& VERGOLINO, 2001, p. 6-7). 
tintas regiões do território sergipano: Laranjeiras e Capela, em Cotinguiba, principal reduto açucareiro da província; Itabaianinha, tal como Estância localizada na Zona da Mata Sul; Vila Nova, no Agreste-Sertão do São Francisco, “(...) beneficiada pela existência do pequeno porto fluvial e pela diversificação de atividades econômicas: pesca, pecuária, lavouras de algodão e arroz"; e Simão Dias, no Agreste-Sertão Sul, a qual, situada “(...) em rota terrestre de comércio com o sertão baiano, era dedicada à pecuária e agricultura voltada para o consumo local e regional." (PASSOS SUBRINHO, 2001, p. 9). ${ }^{56}$

Uma vez mais, verificamos maiores semelhanças na distribuição dos escravistas (Gráfico 7) em comparação à dos escravos (Gráfico 8). Assim, a participação relativa dos proprietários sergipanos das menores posses de cativos oscilou entre um mínimo de 65,7\% (Simão Dias) e um máximo de $80,2 \%$ (Laranjeiras); por sua vez, nos plantéis de maior tamanho viviam de $30,1 \%$ (Simão Dias) a $54,8 \%$ (Vila Nova) dos cativos computados. Os porcentuais correlatos, na São Cristóvão de 1870, igualaram-se, respectivamente, a $62,5 \%$ e $24,7 \%$. Dos cinco municípios sergipanos considerados, é o de Simão Dias o que apresenta a estrutura da posse de escravos mais parecida com a da paróquia fluminense.

56 Essas cinco localidades sergipanas são aquelas cujas listas de classificação, dentre as 14 analisadas por Passos Subrinho, proporcionam, segundo o autor, "(...) as melhores amostras, ou seja, as que correspondem no minimo a 50\% dos escravos matriculados.” (PASSOS SUBRINHO, 2001, p. 6). Ao compararmos o perfil da estrutura da posse de cativos observado nesses municípios sergipanos - cf. Gráficos 7 e 8 - com os resultados sobre Pernambuco fornecidos na nota anterior, percebemos que estes últimos mostram-se mais distantes daqueles observados para São Cristóvão. De fato, por exemplo, o peso relativo dos escravistas de menor porte (com l a 5 cativos), tanto no Agreste como no Sertão pernambucanos, era menor do que sua participação em qualquer das 5 localidades de Sergipe (ainda que nestas últimas a faixa de tamanho em questão fosse de 1 a 3 escravos); outrossim, o porcentual dos escravos possuídos pelos menores proprietários em Pernambuco era inferior ao porcentual correlato verificado nos municípios sergipanos. 


\section{GRÁFICO 8 - DISTRIBUIÇÃO DOS ESCRAVOS SEGUNDO FAIXAS DE TAMANHO DOS PLANTÉIS (SÃO CRISTÓVÃO, 1870; DIVERSAS LOCALIDADES DO SERGIPE, 1873/75)}

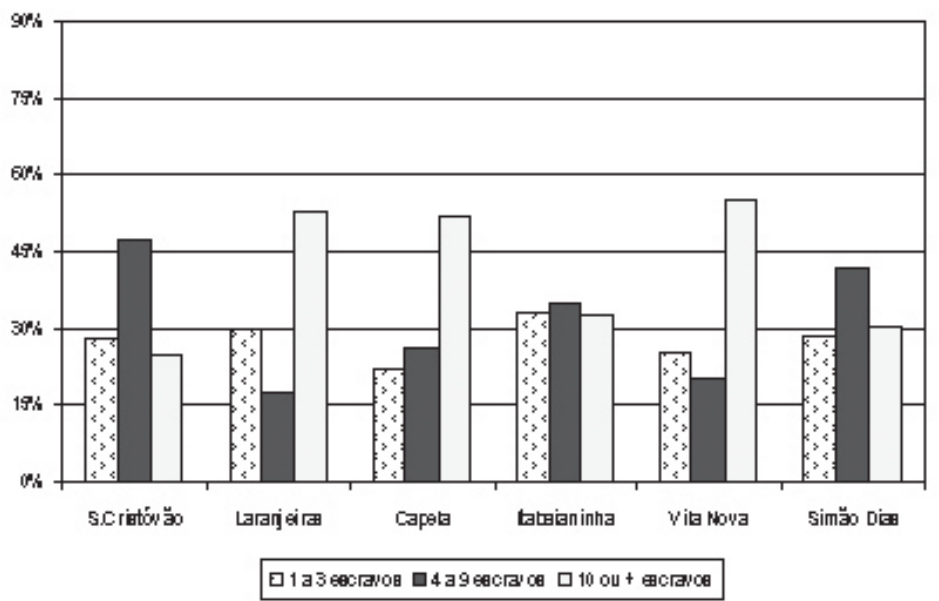

Outros perfis da estrutura da posse de escravos semelhantes ao de São Cristóvão são os observados no conjunto de localidades paranaenses estudado por Gutiérrez Gallardo - Antonina, Guaratuba e Paranaguá, no litoral; Castro, Curitiba, Lapa, Palmeira, Ponta Grossa e São José dos Pinhais, no planalto -, bem como nos municípios das Minas Gerais analisados por Paiva e Libby - Paracatu, no Noroeste da província, e, no Oeste mineiro, Santo Antônio do Monte, Patos e Dores da Marmelada. ${ }^{57}$ As distribuições de escravistas e de escravos segundo faixas de tamanho dos plantéis, para os quatro municípios mineiros (nas décadas de 1830 e de 1870), as nove localidades paranaenses (em 1804 e 1824), bem como para São Cristóvão, vão representadas, respectivamente, nos Gráficos 9 e 10.

57 As fontes documentais utilizadas por Gutiérrez Gallardo foram as listas nominativas de habitantes referentes aos anos de 1804 e 1824 e os indicadores estatísticos por ele calculados foram por nós fornecidos na Tabela 11 (cf. GUTIÉRREZ GALLARDO, 1986). Por sua vez, Paiva e Libby valeram-se, para 1831/32, também de arrolamentos nominativos, nos quais foram computados 7.162 cativos e 1.435 proprietários, cifras que estão subjacentes ao valor da média $(5,0)$ informado na Tabela 10; já os dados atinentes à década de 1870 originaram-se das matrículas de escravos, nas quais foram listados 5.711 cativos distribuídos por 1.566 escravistas (três desses manuscritos são datados de 1873 e, o outro, de 1875; (cf. PAIVA \& LIBBY, 1995). 
Quanto às Gerais, observam Paiva e Libby,

"Os municipios do Oeste Mineiro (...) eram bem representativos da economia diversificada voltada para o mercado interno que (...) caracterizava boa parte das Minas Gerais no Oitocentos. É provável que a agricultura de Paracatu tenha sido menos comercializada que a dos outros municipios devido a seu isolamento com relação aos mercados, mas desde 1809 a região já enviava boiadas para a cidade do Rio de Janeiro (...) e as listas nominativas de 1831-1832 indicam que tanto lá quanto no Oeste Mineiro a induistria têxtil doméstica era florescente.” (PAIVA \& LIBBY, 1995, p. 216).

Os autores em tela, ademais, confrontam seus informes atinentes aos anos $1870 \mathrm{com}$ aqueles presentes nas listas nominativas de 1831-32. ${ }^{58}$

\section{GRÁFICO 9 - DISTRIBUIÇÃO DOS ESCRAVISTAS SEGUNDO FAIXAS DE TAMANHO DOS PLANTÉIS (PARANÁ, 1804 E 1824; SÃO CRISTÓVÃO, 1870; NOROESTE E OESTE MINEIROS, $1831 / 32,1873 / 75)$}

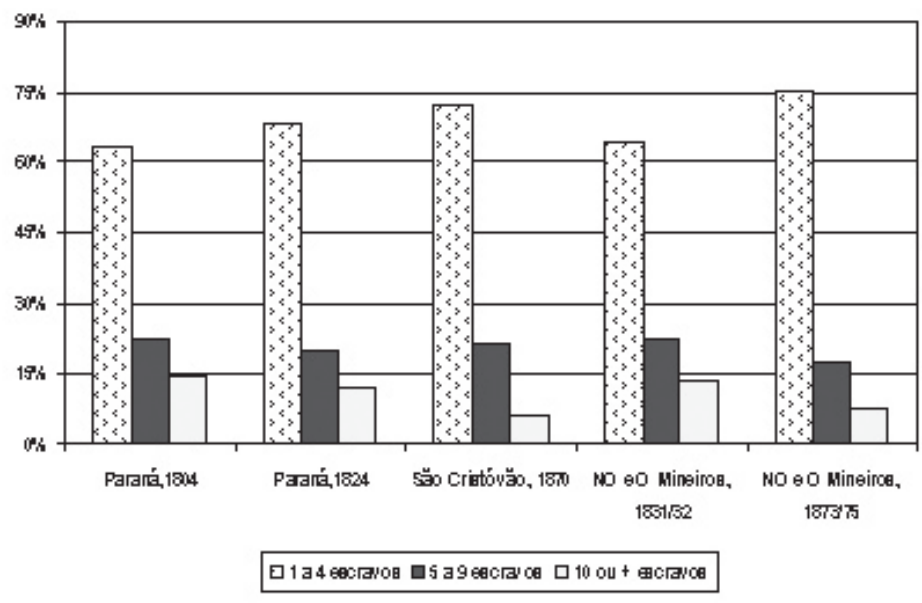

58 "Para efetuar uma comparação entre os dados das matriculas (...) e os das listas nominativas foram escolhidas treze destas, todas originando de distritos localizados nas regiôes descritas acima [Noroeste e Oeste de Minas Gerais]. O resultado é uma afinidade geográfica aproximada, uma vez que as populaçôes distritais não necessariamente coincidem com as arroladas nas matriculas." (PAIVA \& LIBBY, 1995, p. 216). 
GRÁFICO 10 - DISTRIBUIÇÃO DOS ESCRAVOS SEGUNDO FAIXAS DE TAMANHO DOS PLANTÉIS (PARANÁ, 1804 E 1824; SÃO CRISTÓVÃO, 1870; NOROESTE E OESTE MINEIROS, $1831 / 32,1873 / 75)$

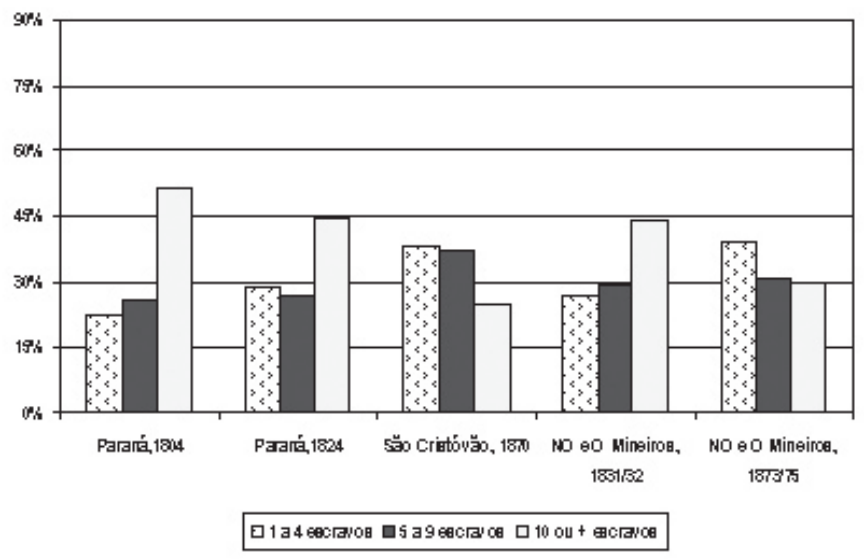

São bastante nítidas as semelhanças entre as distribuições de proprietários fluminenses e mineiros no decênio de 1870 (Gráfico 9); quanto aos cativos (Gráfico 10), ainda que novamente percebamos a menor participação relativa dos escravos vivendo na terceira faixa de tamanho dos plantéis de São Cristóvão vis-à-vis aos do Noroeste e Oeste de Minas Gerais, é igualmente perceptível que o perfil da distribuição dos cativos nos municípios mineiros, comparado aos concernentes a todas as demais localidades tomadas em torno a 1870 (cf. Gráficos 6 e 8 e com a única exceção, talvez, da localidade sergipana de Simão Dias), é o que mais se aproxima do verificado na freguesia objeto de nossa análise. Além disso, são dignas de nota as transformações vivenciadas, num intervalo temporal de 40 anos, pela estrutura da posse de cativos nas regiões selecionadas das Minas Gerais. Elevou-se a importância relativa dos escravistas de menor porte, bem como o peso relativo de seus cativos no total da escravaria, resultado que surpreendeu Paiva e Libby:

"Dado que, com o passar das décadas, esta atípica economia escravista [marcada pela diversidade econômica e pela orientação para o mercado interno] tendeu a se consolidar, seria razoável esperar que a população escrava ficasse cada vez mais concentrada nas posses de tamanho médio, provavelmen- 
te à custa das grandes e pequenas posses. A participação das posses de 30 ou mais escravos, de fato, diminuiu drasticamente durante o período em tela, mas a participação dos pequenos proprietários aumentou consideravelmente, enquanto a das posses médias caiu moderadamente (...). O que parece ter ocorrido foi uma fragmentação que beneficiou os pequenos proprietários de escravos." (PAIVA \& LIBBY, 1995, p. 222).

Consideradas as localidades do Paraná, notamos novamente as similaridades com São Cristóvão em termos da distribuição dos escravistas, sobretudo em 1824 (Gráfico 9). A distribuição dos escravos (Gráfico 10) mostrou maiores disparidades, destacando-se a mais elevada participação dos cativos inseridos nos plantéis com 10 ou mais escravos: 44,5\% em 1824 e 51,8\% em 1804, proporção que atingiu tão-somente cerca de um quarto em São Cristóvão. ${ }^{60}$ Nas palavras de Gutiérrez Gallardo,

\section{"A distribuição da propriedade de escravos correlacionou-se, no Paraná, com as características da ocupação dos senhores, e decorre do tipo de economia local não atrelada ao comércio ultramarino. Os maiores proprietários, escassos em número, apareceram geralmente vinculados às atividades da pecuária e, portanto, com residência nas localidades do planalto, à di- ferença dos proprietários de menor porte, os mais numerosos, que morando quer no litoral, quer no planalto, desenvolveram pequena produção agricola para o próprio consumo e eventuais excedentes para troca. Todavia, o fato marcante revelado pela análise da estrutura de propriedade de escravos é a existência,}

59 Convém reproduzir também a ressalva feita pelos autores: "Na verdade, a mais difícil das operaçôes realizadas na manipulação das matriculas de escravos foi a reconstituição de posses individuais. Uma vez que os escravos eram registrados de acordo com sua classificação, cativos pertencentes ao mesmo senhor poderiam ficar dispersos pelas matriculas. (...) A total ausência de uniformidade nas anotaçôes dos nomes de proprietários provavelmente faz com que nossa compilação seja imperfeita e, portanto, o peso das pequenas posses talvez seja um pouco exagerado. Não obstante, é perfeitamente claro que a participação dos pequenos proprietários havia aumentado consideravelmente.” (PAIVA \& LIBBY, 1995, p. 222, nota de rodapé n. 17).

60 Vale apontar uma peculiaridade interessante identificada nas localidades paranaenses: "Em geral, os grandes proprietários tinham a característica de possuirem mais de uma propriedade, deslocando freqüentemente, conforme a conjuntura, os escravos de uma para a outra propriedade. Em 1804 foram encontrados onze senhores donos de duas propriedades cada um, cinco possuindo 3 propriedades e outros dois compareceram com 4 propriedades cada um. A média de escravos possuidos por estes 18 proprietários com mais de um domicilio era de 40 cativos.” (GUTIÉRREZ GALLARDO, 1986, p. 40). 
no Paraná, de uma sociedade pontilhada de pequenos senhores.” (GUTIÉRREZ GALLARDO, 1986, p. 38).

Em suma, levando em conta todas as localidades que compõem os Gráficos 5 a 10, e independente da multiplicidade de situações consideradas, verificamos que, durante o intervalo temporal de cerca de um século, desde meados da década de 1770 até meados do decênio de 1870 , portanto até às vésperas da abolição, uma esmagadora maioria dos escravistas era detentora de poucos cativos e a maioria absoluta dos escravos - com as exceções de Laranjeiras, Capela e Vila Nova, em Sergipe, e do conjunto de localidades paranaenses em 1804, onde as participações atingiam, respectivamente, $47,1 \%, 48,1 \%, 45,2 \%$ e $48,2 \%$ - vivia em plantéis de pequeno ou médio porte, assim entendidos, em cada caso, aqueles inseridos nas primeira e segunda das faixas de tamanho contempladas.

Este, pois, repisemos, o panorama vislumbrado a partir do conjunto de localidades cujos indicadores estatísticos anunciavam, de antemão, estruturas da posse de cativos não muito destoantes daquela por nós encontrada em São Cristóvão em 1870.

\section{GRÁFICO 11 - DISTRIBUICÃO DOS ESCRAVISTAS SEGUNDO FAI- XAS DE TAMANHO DOS PLANTÉIS}

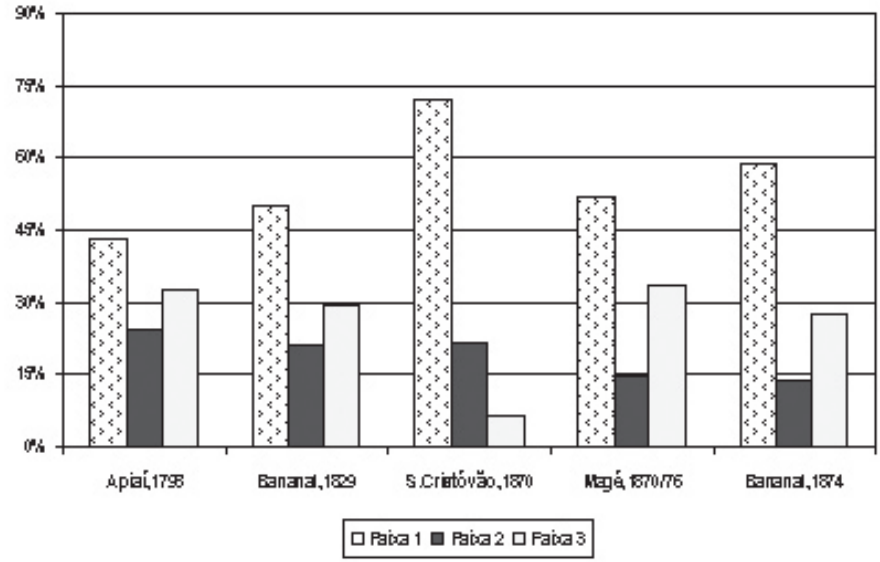

Faixa 1 = l a 4 escravos em Apiaí, Bananal, Magé e São Cristóvão.

Faixa 2 = 5 a 9 escravos em Apiaí, Bananal e São Cristóvão; 5 a 10 em Magé.

Faixa 3 = 10 ou + escravos em Apiaí, Bananal e São Cristóvão; 11 ou + em Magé. 
Com o intuito de fornecermos um contraponto, selecionamos, para a construção dos Gráficos 11 e 12, quatro dentre as situações que, consoante a análise das Tabelas 10, 11 e 12, mais se apartavam da freguesia fluminense, duas delas tomadas na segunda metade do Oitocentos, e duas em período anterior. Apresentamos, por conseguinte, as distribuições, por distintas faixas de tamanho dos plantéis, dos escravistas (Gráfico 11) e de seus respectivos escravos (Gráfico 12) existentes em Apiaí (1798), Bananal (1829 e 1874) e Magé (1870/6), lado a lado com as distribuiçóes correlatas calculadas para São Cristóvão.

\section{GRÁFICO 12 - DISTRIBUIÇÃO DOS ESCRAVOS SEGUNDO FAIXAS DE TAMANHO DOS PLANTÉIS}

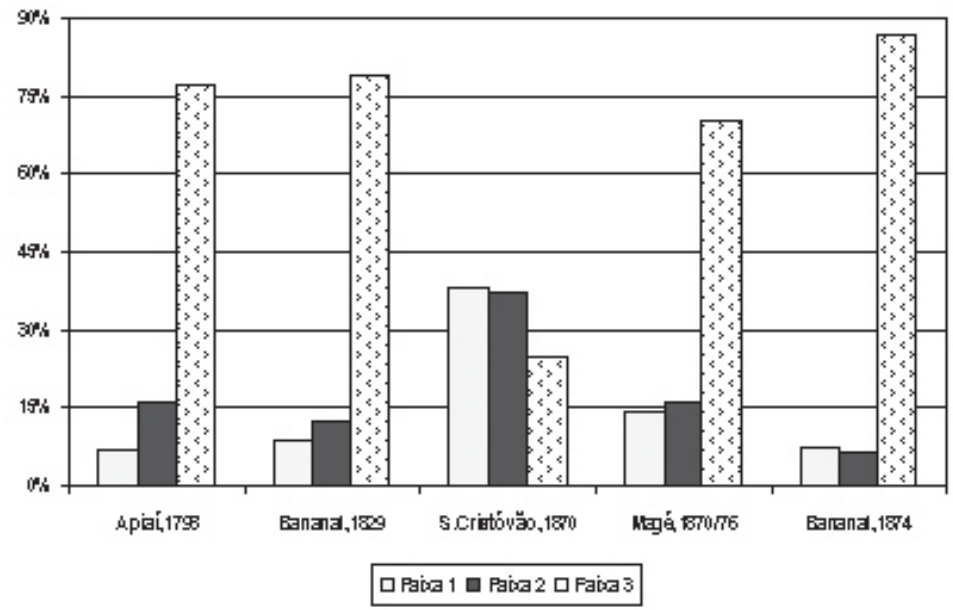

Faixa 1 = l a 4 escravos em Apiaí, Bananal, Magé e São Cristóvão.

Faixa 2 = 5 a 9 escravos em Apiaí, Bananal e São Cristóvão; 5 a 10 em Magé.

Faixa 3 = 10 ou + escravos em Apiaí, Bananal e São Cristóvão; 11 ou + em Magé.

Como esperado, o cenário modifica-se de maneira importante. Se, até aqui, em todos os casos selecionados, a participação relativa dos escravistas de menor porte fora sempre superior aos três quintos, no Gráfico 11 essa proporção não é atingida por nenhuma das localidades confrontadas com São Cristóvão. Já os proprietários dos plantéis da terceira faixa de tamanho, até aqui nunca perfazendo o peso relativo de $15 \%$ do total de escravistas, agora oscilam em torno do dobro daquela cifra. Analogamente, no tocante aos cativos, como vimos nos gráficos anteriores, apenas em três casos a propor- 
ção dos que viviam nos plantéis de maior tamanho alçava-se ligeiramente acima dos 50\%; no Gráfico 12, tanto em Apiaí como em Bananal e Magé, o porcentual correlato iguala-se, no mínimo, a 70\%, chegando ao máximo de $86,8 \%$ na localidade valeparaibana paulista em 1874 .

De fato, em Bananal, as disparidades com respeito a São Cristóvão encontram seu exemplo mais extremado. Segundo o Recenseamento Geral do Império, de 1872, realizado na província de São Paulo em 1874, a maioria absoluta da população bananalense era de escravos $(53,1 \%)$. Como observa Renato Marcondes, com fundamento nas listas de classificação para várias localidades do Vale do Paraíba paulista, “(...) observamos em Bananal as características mais próximas às da plantation cafeeira. Em nenbum outro lugar verificamos posses cativas tão elevadas e padrão semelhante de concentração da propriedade escrava.” (MARCONDES, 2000, p. 24). É certo. Mas há que concordar também com as ponderações seguintes, desse mesmo autor:
"Entretanto, Bananal constituía apenas uma das várias lo- calidades da região. (...) Até mesmo no caso mais próximo da plantation notamos a presença significativa em termos do total de escravistas e da escravaria dos pequenos e médios proprietá- rios de cativos. Embora mais envolvidos com a produção para o mercado interno, estes individuos também produziam café em quantidades significativas. (...) Destarte, o dinamismo eco- nômico e demográfico valeparaibano não se restringia apenas aos membros da grande lavoura cafeeira." (MARCONDES, 2000, p. 25).

Cremos que, com as várias localidades contempladas nesta comparação, patenteia-se que tais ponderaçóes estendem-se para além do contexto valeparaibano, abrangendo toda a diversidade que caracteriza o escravismo no Brasil.

\section{CONSIDERAÇÕES FINAIS}

Neste artigo, com base em um recenseamento manuscrito realizado em 1870, estudamos a estrutura da posse de escravos de São Cristóvão que, à 
época - figurando entre as dezenove freguesias pelas quais se distribuía a população da cidade do Rio de Janeiro -, definia-se como uma das paróquias "de dentro", como eram identificadas as freguesias mais próximas do porto, as quais se distinguiam por um desenvolvimento urbano relativamente mais intenso. Havia na paróquia cerca de quatro centenas de escravistas detentores de uma população cativa de pouco mais de 1.500 indivíduos, contingente este que se fazia presente em aproximadamente um quarto dos domićlios existentes.

Além dos traços característicos decorrentes dessa natureza urbana - a exemplo da elevada freqüência de escravistas dedicados ao comércio, possuidores de mais de um terço do total de cativos -, a escravaria de São Cristóvão via-se igualmente marcada pelo predomínio numérico das mulheres, ao que tudo indica resultado de um movimento de drenagem da mão-de-obra masculina para o meio rural. Tal movimento, evidentemente, refletia as duas décadas de escravidão já transcorridas desde o encerramento do tráfico transatlântico de cativos, assim como as peculiaridades do tráfico interprovincial daquela mercadoria humana.

Não obstante o interesse suscitado pelas especificidades presentes no caso em tela, ainda mais relevante, cremos nós, é a verificação, em São Cristóvão, de um perfil da estrutura da posse de escravos que reproduz um mesmo padrão geral válido para o Brasil. De um lado, a disseminação relativamente ampla da posse escrava pela população livre de nossa sociedade escravista, evidenciada na maioria significativa de escravistas detentores de um número reduzido de cativos: eram $78,6 \%$ os proprietários, na freguesia fluminense, com 5 ou menos escravos. De outro, no que respeita aos cativos, a expressiva participação daqueles integrantes de plantéis de pequeno e médio porte: $88,6 \%$ da população escrava, em São Cristóvão, estavam inseridos em plantéis com 15 ou menos cativos.

De fato, ao procedermos à comparação entre alguns traços da estrutura da posse de escravos em São Cristóvão e os observados em diversas outras localidades e/ou regiões do Brasil escravista, no decurso dos séculos XVIII e XIX, pudemos verificar, mesmo nas situações vincadas por maiores diferenças $v i s$ - $\grave{a}$-vis à paróquia fluminense, que tais disparidades ocorreram dentro de limites que não implicaram a negação daquele padrão geral básico. Tais são 
os casos, por exemplo, de Bananal, onde se desenvolveu de forma ímpar a lavoura cafeeira valeparaibana paulista; de Magé, no Rio de Janeiro, onde uma produção alimentar com vistas à comercialização no mercado interno ensejou um perfil de distribuição da riqueza que, guardadas as devidas proporções, aproximava-se bastante daquele próprio das áreas agroexportadoras; ou ainda de Apiaí, novamente em São Paulo, onde dois breves surtos mineradores no decurso do Setecentos deram lugar a uma hierarquia social em boa medida petrificada pelos escravistas que decidiram permanecer, mesmo na etapa de decadência econômica, na localidade em que haviam deitado raízes.

Se o mencionado padrão geral básico não se viu contraditado por esses exemplos mais apartados, sua corroboração foi evidenciada, à saciedade, pelas situaçôes nas quais a estrutura da posse de cativos apresentou maiores semelhanças com a por nós observada em São Cristóvão.

Tais situações abarcavam desde o decadente núcleo urbano mineiro de Vila Rica em 1804, passando pela paulista Mogi das Cruzes, com sua modesta agricultura destinada ao abastecimento dos mercados locais, até a localidade sergipana de Simão Dias na década de 1870, dedicada à pecuária e à produção agrícola de mercado interno; desde a diversificada economia das regiões de Paracatu e do Oeste mineiro, passando pelas vilas paranaenses e do Caminho do Sul - aí incluída Sorocaba e seu relevante comércio de animais -, até as localidades piauienses de Teresina e Oeiras, nas quais a agroexportação integrava um conjunto de atividades econômicas no qual se notava, uma vez mais, a prevalência da produção de gêneros de abastecimento interno. Tais situações abrangiam, outrossim, as regiões - consideradas nos períodos anteriores ao maior desenvolvimento das lavouras de exportação -, cuja estrutura da posse de escravos viria a distanciar-se da verificada em São Cristóvão a partir do aludido desenvolvimento, a exemplo do Vale do Paraíba e do litoral norte da província de São Paulo.

Enfim se, como sabido, panos de fundo socioeconômicos distintos podem dar suporte a populações cujas estruturas demográficas apresentam perfis estatísticos em boa medida semelhantes, este é o caso do padrão de distribuição da propriedade escrava no Brasil dos séculos XVIII e XIX. Nesse 
padrão figuravam, de forma inequívoca, vale a pena repisar, como escravista majoritário, o que possuía poucos cativos, e como escravo típico o que vivia fora do ambiente característico da plantation. Estes os traços delineadores da estrutura da posse de escravos mais saliente do escravismo brasileiro.

\section{REFERÊNCIAS BIBLIOGRÁFICAS}

CARVALHO, José Alberto Magno de; SAWYER, Diana Oya; RODRIGUES, Roberto do Nascimento. Introdução a alguns conceitos básicos e medidas em demografia. Belo Horizonte: ABEP, 1994.

CASTRO, Hebe Maria da Costa Mattos Gomes de. Das cores do silêncio: os significados da liberdade no sudeste escravista - Brasil, século XIX. Rio de Janeiro: Arquivo Nacional, 1995.

Collecção das leis do império do Brasil de 1872. Rio de Janeiro: Typographia Nacional, 1873, v. 2.

COSTA, Iraci del Nero da. Vila Rica: população (1719-1826). São Paulo: IPE/USP, 1979.

Populaçôes mineiras: sobre a estrutura populacional de alguns núcleos mineiros no alvorecer do século XIX. São Paulo: IPE/USP, 1981.

. Nota sobre ciclo de vida e posse de escravos. História: Questôes é Debates, v. 4, n. 6, p. 121-127, jun. 1983.

COSTA, Iraci del Nero da; NOZOE, Nelson Hideiki. Elementos da estrutura de posse de escravos em Lorena no alvorecer do século XIX. Estudos Econômicos, v. 19, n. 2, p. 319-345, maio/ago. 1989.

COSTA, Iraci del Nero da; SLENES, Robert W.; SCHWARTZ, Stuart B. A família escrava em Lorena (1801). Estudos Econômicos, v. 17, n. 2, p. 245-295, maio/ago. 1987.

FERNÁNDEZ, Ramón V. García. Transformações econômicas no litoral norte paulista (1778-1836). 1992. Tese (Doutorado), FEA/USP, São Paulo. (Mimeografado).

GRAF, Márcia E. de Campos. População escrava da Provincia do Paraná, a partir das listas de classificação para emancipação (1873 - 1886). 1974. Dissertação (Mestrado), Universidade Federal do Paraná, Curitiba. (Mimeografado).

GUTIÉRREZ GALLARDO, Darío Horacio. Senhores e escravos no Paraná, 1800-1830. 1986. Dissertação (Mestrado), FEA/USP, São Paulo. (Mimeografado).

IBGE (MSS). Rolo n. 332: volume 1-3 com 286 páginas e volume 4-5 com 326 páginas; Rolo n. 333: volume 6-8 com 388 páginas e volume 9- 
11 com 303 páginas; Rolo n. 334: volume 12-14 com 171 páginas. Todos referentes ao Recenseamento do Brasil de 1870; os volumes são manuscritos pelos próprios moradores da "Parochia de São Cristóvão do Município da Corte. Rio de Janeiro: IBGE-BICEN, 1980, microfilme.

LOBO, Eulalia Maria Lahmeyer. História do Rio de Janeiro (do capital comercial ao capital industrial e financeiro). Rio de Janeiro: IBMEC, 1978. 2 vols.

LUNA, Francisco Vidal. Minas Gerais: escravos e senhores - análise da estrutura populacional e econômica de alguns centros mineratórios (1718-1804). São Paulo: IPE/USP, 1981.

. Posse de escravos em Sorocaba (1778-1836). Primeiro Seminário do Centenário da Abolição do Escravismo: da Época Colonial à Situação do Negro na Atualidade. São Paulo: FEA/USP, 1986. (Mimeografado).

- São Paulo: população, atividades e posse de escravos em vinte e cinco localidades (1777-1829). Estudos Econômicos, São Paulo: IPE/ USP, v. 28, n. 1, p. 99-169, jan./mar. 1998.

LUNA, Francisco Vidal; COSTA, Iraci del Nero da. Posse de escravos em São Paulo no início do século XIX. Estudos Econômicos, São Paulo: IPE/USP, v. 13, n. 1, p. 211-221, jan./abr. 1983.

MARCONDES, Renato Leite. A arte de acumular na economia cafeeira: Vale do Paraíba, século XIX. Lorena: Editora Stiliano, 1998.

- A propriedade escrava no Vale do Paraiba paulista durante a década de 1870. Texto para Discussão. Série Economia (TD-E/10). São Paulo: FEA/USP-Ribeirão Preto, 2000. (Mimeografado).

MARCONDES, Renato Leite; FALCI, Miridan Britto Knox. Escravidão e reprodução no Piaui: Oeiras e Teresina (1875). Texto para Discussão. Série Economia (TD-E/26). São Paulo: FEA/USP-Ribeirão Preto, 2001. (Mimeografado).

MELlO, Zélia Maria Cardoso de. Metamorfoses da riqueza, São Paulo, 1845-1895: contribuição ao estudo da passagem da economia mercantil-escravista à economia exportadora capitalista. São Paulo: Hucitec/Prefeitura do Município de São Paulo, 1985.

METCALF, Alida C. Families of planters, peasants and slaves: strategies for survival in Santana de Parnaíba, Brazil, 1720-1820. Austin: The University of Texas at Austin, 1983.

MOTTA, José Flávio. Corpos escravos, vontades livres: posse de cativos e família escrava em Bananal (1801-1829). São Paulo: FAPESP/Annablume, 1999. 
MOTTA, José Flávio; NOZOE, Nelson; COSTA, Iraci del Nero da. $A$ posse de escravos em uma paróquia fluminense: São Cristóvão, 1870. São Paulo: N.E.H.D.-FEA/USP, 2002. (Mimeografado).

MOURA, Ana Maria da Silva. Cocheiros e carroceiros: homens livres no Rio de senhores e escravos. São Paulo: Hucitec, 1988.

PAIVA, Clotilde Andrade; LIBBY, Douglas Cole. Caminhos alternativos: escravidão e reprodução em Minas Gerais no século XIX. Estudos Econômicos, São Paulo: IPE/USP, v. 25, n. 2, p. 203-233, maio/ago. 1995.

PASSOS SUBRINHO, Josué Modesto dos. Reordenamento do trabalho: trabalho escravo e trabalho livre no Nordeste açucareiro; Sergipe, 1850/1930. Aracaju: Funcaju, 2000.

- Propriedade escrava e declínio do escravismo na Província de Sergipe. Anais do IV Congresso Brasileiro de História Econômica $/ 5^{a}$ Conferência Internacional de História de Empresas. [CD ROM]. São Paulo: ABPHE - FEA/USP, 2001.

RANGEL, Armênio de Souza. Escravismo e riqueza: formação da economia cafeeira no município de Taubaté, 1765-1835. 1990. Tese (Doutorado), FEA/USP, São Paulo. (Mimeografado).

RELATÓRIO sobre o Arrolamento da População do Município da Corte em 1870. In: Relatório Apresentado ao Ministro e Secretário D'Estado dos Negócios do Império pela Comissão Encarregada da Direção dos Trabalhos do Arrolamento da População do Município da Corte a que se Procedeu em Abril de 1870. Rio de Janeiro: Typographia Perseverança, 1871.

SAMPAIO, Antonio Carlos Jucá de. Magé na crise do escravismo: sistema agrário e evolução econômica na produção de alimentos (1850-1888). 1994. Dissertação (Mestrado), ICHF/UFF, Niterói. (Mimeografado).

SANTOS, Francisco Agenor de Noronha. As freguesias do Rio antigo. Rio de Janeiro: Edições O Cruzeiro, 1965.

SANTOS, Jonas Rafael dos. Escravos e senhores em Mogi das Cruzes: a estrutura da posse de escravos, 1777-1829. 1965. Dissertação (Mestrado) FHDSS/UNESP, campus de Franca, 2001. (Mimeografado).

SCHLICHTHORST, C. O Rio de Janeiro como é, 1824-1826. Rio de Janeiro: Livraria-Editora Zélio Valverde, 1943.

SCHWARTZ, Stuart B. Padrões de propriedade de escravos nas Américas: nova evidência para o Brasil. Estudos Econômicos, São Paulo: IPE/USP, v. 13, n. 1, p. 259-287, jan./abr. 1983.

. Segredos internos: engenhos e escravos na sociedade colonial, 15501835. São Paulo: Cia. das Letras, 1988. 
SLENES, Robert W. Escravidão e família: padrões de casamento e estabilidade familiar numa comunidade escrava (Campinas, século XIX). Estudos Econômicos, v. 17, n. 2, p. 217-227, maio/ago. 1987.

TEIXEIRA, Heloísa Maria. Reprodução e familias escravas em Mariana, 1850-1888. 2001. Dissertação (Mestrado). FFLCH/USP, São Paulo. (Mimeografado).

VALENTIN, Agnaldo. Nem Minas, nem São Paulo: economia e demografia na localidade paulista de Apiaí (1732-1835). 2001. Dissertação (Mestrado), FFLCH/USP, São Paulo. (Mimeografado).

VERSIANI, Flávio Rabelo; VERGOLINO, José Raimundo O. Posse de escravos e estrutura de ativos no Agreste e Sertão de Pernambuco. Anais do XXIX Encontro Nacional de Economia. [CD ROM]. Belém: ANPEC, 2001.

Este artigo é dedicado à memória de Geísa Firmo Gonçalves, jovem professora, morta aos vinte anos, em junho de 2000, pelos tiros decorrentes da ação desastrosa de um soldado da PM que tentava atingir o assaltante do ônibus no qual Geísa e outras pessoas foram mantidas como reféns perto do Parque Lage, Jardim Botânico, na zona sul do Rio de Janeiro.

Os autores, membros do N.E.H.D. - Núcleo de Estudos em História Demográfica da FEA/USP, agradecem os comentários à primeira parte do texto efetuados pelo Prof. Dr. Flávio Rabelo Versiani, da UnB, bem como as sugestóes dos pareceristas da Estudos Econômicos.

(Recebido em setembro de 2002. aceito para publicação em julho de 2003). 